\title{
Agricultural practices altered soybean seed protein, oil, fatty acids, sugars, and minerals in the Midsouth USA
}

\author{
Nacer Bellaloui ${ }^{1}{ }^{*}$, H. Arnold Bruns ${ }^{2}$, Hamed K. Abbas ${ }^{3}$, Alemu Mengistu ${ }^{4}$, Daniel K. Fisher ${ }^{2}$ and \\ Krishna N. Reddy ${ }^{2}$ \\ ${ }^{1}$ Crop Genetics Research Unit, Plant Physiology, United States Department of Agriculture - Agricultural Research Service, Stoneville, MS, USA \\ ${ }^{2}$ Crop Production Systems Research Unit, Crop Production, United States Department of Agriculture - Agricultural Research Service, Stoneville, MS, USA \\ ${ }^{3}$ Biological Control of Pests Research Unit, Biological Control, United States Department of Agriculture - Agricultural Research Service, Stoneville, MS, USA \\ ${ }^{4}$ Crop Genetics Research Unit, Pathology, United States Department of Agriculture - Agricultural Research Service, Jackson, TN, USA
}

\section{Edited by:}

Antonio M. De Ron, National Spanish

Research Council, Spain

\section{Reviewed by:}

Leonardo Velasco, Institute for Sustainable Agriculture - National Spanish Research Council, Spain Rouxlene Van Der Merwe, University of the Free State, South Africa

\section{*Correspondence:}

Nacer Bellaloui, Crop Genetics Research Unit, Plant Physiology, United States Department of Agriculture - Agricultural Research Service, 141 Experiment Station Road, Stoneville, MS 38776, USA e-mail: nacer.bellaloui@ars.usda.gov
Information on the effects of management practices on soybean seed composition is scarce. Therefore, the objective of this research was to investigate the effects of planting date (PD) and seeding rate (SR) on seed composition (protein, oil, fatty acids, and sugars) and seed minerals ( $\mathrm{B}, \mathrm{P}$, and Fe) in soybean grown in two row-types (RTs) on the Mississippi Delta region of the Midsouth USA. Two field experiments were conducted in 2009 and 2010 on Sharkey clay and Beulah fine sandy loam soil at Stoneville, MS, USA, under irrigated conditions. Soybean were grown in $102 \mathrm{~cm}$ single-rows and $25 \mathrm{~cm}$ twin-rows in $102 \mathrm{~cm}$ centers at SRs of 20,30,40, and 50 seeds $\mathrm{m}^{-2}$. The results showed that in May and June planting, protein, glucose, $\mathrm{P}$, and $\mathrm{B}$ concentrations increased with increased SR, but at the highest SRs ( 40 and 50 seeds $\mathrm{m}^{-2}$ ), the concentrations remained constant or declined. Palmitic, stearic, and linoleic acid concentrations were the least responsive to SR increases. Early planting resulted in higher oil, oleic acid, sucrose, B, and P on both single and twin-rows. Late planting resulted in higher protein and linolenic acid, but lower oleic acid and oil concentrations. The changes in seed constituents could be due to changes in environmental factors (drought and temperature), and nutrient accumulation in seeds and leaves. The increase of stachyose sugar in $\mathbf{2 0 1 0}$ may be due to a drier year and high temperature in 2010 compared to 2009; suggesting the possible role of stachyose as an environmental stress compound. Our research demonstrated that PD, SR, and RT altered some seed constituents, but the level of alteration in each year dependent on environmental factors such as drought and temperature. This information benefits growers and breeders for considering agronomic practices to select for soybean seed nutritional qualities under drought and high heat conditions.

Keywords: seed protein, fatty acids, sugars, minerals, twin-rows, seeding rate, planting date

\section{INTRODUCTION}

Soybean is a major oil and protein crop globally. The seed quality is determined by its composition, including protein, oil, fatty acids, sugars, and minerals. Soybean seed contains on a dry weight basis about 380 to $420 \mathrm{~g} \mathrm{~kg}^{-1}$ protein, 190 to $230 \mathrm{~g} \mathrm{~kg}^{-1}$ oil, and based on the total oil, 120 to $130 \mathrm{~g} \mathrm{~kg}^{-1}$ palmitic acid, 30 to $40 \mathrm{~g} \mathrm{~kg}^{-1}$ oleic acid, 480 to $580 \mathrm{~g} \mathrm{~kg}^{-1}$ linoleic acid, and 50 to $80 \mathrm{~g} \mathrm{~kg}^{-1}$ linolenic acid. They also contain sugars such as monosaccharides (glucose and fructose), disaccharide (sucrose), and oligosaccharides (raffinose and stachyose). The mineral composition includes $\mathrm{P}, \mathrm{K}, \mathrm{Ca}, \mathrm{Mn}, \mathrm{Zn}, \mathrm{Fe}$, and $\mathrm{B}$ that are essential for human nutrition, and deficiency of these minerals in the diet can lead to human malnutrition and health problems (Samman et al., 1998; Bouis, 2003; Devirian and Volpe, 2003; Lu etal., 2008). It was reported that over 3 billion people are suffering from malnutrition of minerals, especially iron and zinc (Welch and Graham, 2004; Lu et al., 2008; White and Broadley, 2009). Higher oleic, and lower linoleic and linolenic acids are desirable because they contribute to oil stability. Lower raffinose and stachyose and higher sucrose, fructose, and glucose are desirable because mono- and disaccharides contribute to flavor and taste, but high raffinose and stachyose are indigestible and cause flatulence and diarrhea in non-ruminant animals (Liu, 1997). Seed composition constituents are genetically controlled; however, they are known to be influenced by biotic and abiotic factors such as genotype, maturity, growing season, geographic location, and agronomic practices (Harue and Hirokadzu, 1971; Chapman et al., 1976; Chy and Sheldon, 1979; Wilcox and Cavins, 1995).

Traditionally soybeans in the Midsouth are grown in singlerows, and between row-spacings of 88 to $102 \mathrm{~cm}$ are common for soybeans produced in the Mississippi Delta (Ebelhar, 2010). With the commercialization and availability of twin-row-planters (Mascagni et al., 2008; Bruns, 2011), more farmers in the Mississippi delta are becoming interested in twin-row production. Twin-row planters have the capability of planting twin-rows 7.5 to 10 inches (19.1 to $25.4 \mathrm{~cm}$ ) apart. Although yield responses of single-row vs. twin-row planting have been inconsistent across crops, years, and locations, soybean still has the largest 
positive response to yield increase in twin-rows vs. single-row (Mascagni et al., 2008). Also, in the Midsouth, including Mississippi, some growers plant soybean as a double-crop with wheat (Lehrsch et al., 1994; Minor and Wiebold, 1998; Heatherly, 2014), and in this production system, soybeans are usually planted in June. This is considered late planting, as opposed to early planting which usually occurs in April. Late planting exposes soybean to a new environment of drought, heat, photoperiod, and diseases, especially charcoal rot and phomopsis. In the Early Soybean Production System (ESPS) in the Midsouth, soybean cultivars of maturity group (MG) IV and $\mathrm{V}$ are planted in April-May and harvested in August-September (Heatherly, 1999; Ray et al., 2006) to avoid drought stress during late July through early September. In spite of the yield benefit of the ESPS (Heatherly et al., 1999; Ray et al., 2006), poor seed quality (Mengistu and Heatherly, 2006; Mengistu et al., 2007; Smith et al., 2008), and variability of seed constituents (Bellaloui et al., 2008, 2009b) remain a challenge. Therefore, optimizing the ESPS in the Midsouth for higher, sustainable seed quality is critical.

Although limited information is available on the effects of planting date (PD; Schnebly and Fehr, 1993; Jaureguy et al., 2013) and row-spacing (Boydak et al., 2002), and seeding rate (SR) and row-spacing (Bellaloui et al., 2014) on seed composition, to our knowledge there has been no research done on the combined effects of PD, row-type (RT), and SR on seed composition and mineral nutrition. Therefore, the objective of the current research was to evaluate the effects of single- and twin-row plantings (using 102 and $25 \mathrm{~cm}$ on $102 \mathrm{~cm}$ center row-spacing, respectively), early, intermediate, and late planting, and SRs of 20,30, 40, and 50 seeds $\mathrm{m}^{-2}$ on soybean seed composition in sandy and clay soils under the Midsouth agro-ecosystem. Our hypothesis was that PD combined with RT (single- vs. twin) and SR will subject the crop to a new growing environment, altering seed composition constituents.

\section{MATERIALS AND METHODS FIELD MANAGEMENT AND GROWTH CONDITIONS}

An experiment was performed under field conditions in 2009 and 2010 on Sharkey clay (very-fine, smectitic, thermic Chromic Epiaquerts) and sandy loam (Beulah fine sandy loam, coarse-loamy, mixed, active, thermic Typic Dystrudepts) soils in Stoneville, MS, USA. The current research focused on seed nutrition only, and the agronomic component, including yield, was previously published (Bruns, 2011). Field management and growth conditions were described in detail previously (Bruns, 2011). Briefly, single-row plots were planted using an Almaco cone plot planter (Allen Machine Company, Nevada, IA, USA), and twin-row plots were planted using a four unit Monosem NG-3 (Monosem, Edwardsville, KS, USA) twin-row planter set on $102-\mathrm{cm}$ centers and $25 \mathrm{~cm}$ between rows. In the Sharkey clay soil, soybean was planted in 2009 on 22 April, 20 May, and 17 June. In 2010, plantings occurred on 12 April, 11 May, and 2 June. In the sandy loam soil, PDs were 8 April, 11 May, and 8 June in 2009, and 14 April, 11 May, and 17 June in 2010. Cultivar Pioneer brand, 94B73, representative of most of the cultivars grown in the ESPS in the Midsouth was used. For weed control, a pre-plant application of trifluralin [2,6-dinitro- $N, N$-dipropyl-4(trifluoromethyl)aniline] at $0.7 \mathrm{~kg}$ ai ha ${ }^{-1}$ was applied, followed by two post-emergence applications of metolachlor [2-chloro- $\mathrm{N}$-(2ethyl-6-methylphenyl)-N-(2-methoxy-1-methylethyl) acetamide] and glyphosate [2-[(phosphonomethyl)amino]acetic acid] at growth stage V2 to V3 (two to three trifoliolates) and at V5 to V6 (five to six trifoliolates). To control fungus, pyraclostrobin (carbamic acid, [[[[1-(4-cholrophenyl)-H-pyrazol3-yl]oxy]methyl]phenyl]methoxy-,methyl ester) was applied at factory label directions at V5 to V6. The experiments were furrow irrigated starting at R1 (beginning flowering) through R6 (full seed-fill), and an equivalent of $\sim 25 \mathrm{~mm} \mathrm{ha}^{-1}$ water was applied at 10 -days intervals. Soil analysis during the vegetative stage at both sites indicated that there were no nutrient deficiencies in soil in either year. Mature seeds at the R8 growth stage were collected, processed, and analyzed for seed composition constituent concentrations as described below.

\section{SOIL MINERALS, N, S, AND C ANALYSIS}

Soil nutrient analyses were performed at the University of Georgia's Soil, Plant, and Water Laboratory in Athens, GA. Concentrations of $\mathrm{K}$ were analyzed on a $5 \mathrm{~g}$ soil: $20 \mathrm{ml}$ Mehlich- 1 solution and the concentrations were determined using inductively coupled plasma spectrometry. Soil N, S, and C were determined by combusting samples using a $\mathrm{C} / \mathrm{N} / \mathrm{S}$ elemental analyzer having thermal conductivity cells (LECOCNS-2000 elemental analyzer, LECOCorporation, St. Joseph, MI, USA). A $0.25 \mathrm{~g}$ sample of soil was combusted in an oxygen atmosphere at $1350^{\circ} \mathrm{C}$, converting elemental $\mathrm{N}, \mathrm{S}$, and $\mathrm{C}$ into $\mathrm{N}_{2}, \mathrm{SO}_{2}$, and $\mathrm{CO}_{2}$. The gasses were then passed through infrared cells and $\mathrm{N}, \mathrm{S}$, and $\mathrm{C}$ were determined by the elemental analyzer.

\section{LEAF AND SEED MINERALS, N, S, AND C ANALYSIS}

Plant tissue samples were analyzed for different nutrients, including $\mathrm{N}, \mathrm{S}$, and $\mathrm{C}$ ratios. This was done by digesting $0.6 \mathrm{~g}$ of dried, ground plant materials in $\mathrm{HNO}_{3}$ in a microwave digestion system. Samples were ground using a Laboratory Mill 3600 (Perten, Springfield, IL, USA), and the concentration of $\mathrm{K}$ was determined using inductively coupled plasma spectrometry (Thermo Jarrell-Ash Model 61E ICP and Thermo JarrellAsh Autosampler 300; Bellaloui et al., 2011, 2014). For N, C, and $\mathrm{S}$ measurements, a $0.25 \mathrm{~g}$ ground-dried sample was combusted, and the percentages of $\mathrm{C}, \mathrm{N}$ and $\mathrm{S}$ were determined using the C/N/S elemental analyzer (Bellaloui et al., 2011, 2014). For B, P, and Fe, concentrations were determined as described below.

\section{SEED ANALYSIS FOR PROTEIN, OIL, FATTY ACIDS, AND SUGARS}

Mature seeds were analyzed for protein, oil, fatty acids, and sugars according to detailed methods as reported by Bellaloui et al. (2009b, 2010, 2014). Briefly, a 25 g sample of ground seed was analyzed for protein, oil, fatty acids, and sugars by near infrared reflectance (Wilcox and Shibles, 2001; Bellaloui et al., 2009b, 2010) using a diode array feed analyzer AD 7200 (Perten, Springfield, IL, USA). The calibration equation was initially developed by the University of Minnesota using Perten's Thermo Galactic Grams PLS IQ software using conventional chemical protocols with AOAC 
methods (AOAC, 1990a,b). Then, the calibration equation for protein, oil, fatty acids, and sugars has been updated from 6 months to 1 year to insure accuracy and validity of the equation. Seeds at maturity were harvested at $13 \%$ water moisture and seed concentrations for protein, oil, fatty acids, and sugars were immediately performed on $13 \%$ water moisture and expressed on dry weight basis (Wilcox and Shibles, 2001; Boydak et al., 2002; Bellaloui et al., 2010, 2014). The fatty acid concentrations (palmitic, stearic, oleic, linoleic, and linolenic acids) were determined relative to total oils (Bellaloui et al., 2009b, 2014).

\section{SEED GLUCOSE AND FRUCTOSE ANALYSIS}

The glucose level in seeds was measured by an enzymatic reaction using a Glucose (HK) Assay Kit, Product Code GAHK-20 (Sigma-Aldrich Co, St. Louis, MO, USA). A detailed description of the protocol and analysis was previously described by Bellaloui et al. (2014). Briefly, glucose and fructose were phosphorylated by adenosine triphosphate (ATP) and catalyzed by hexokinase, resulting in glucose-6-phosphate (G6P). The produced product (G6P) was then oxidized to 6-phosphogluconate by oxidized nicotinamide adenine dinucleotide (NAD) using glucose-6-phosphate dehydrogenase $(\mathrm{G} 6 \mathrm{PDH})$. The NAD was then reduced to $\mathrm{NADH}$, and the concentration of glucose was determined based on the increase in absorbance at $340 \mathrm{~nm}$. The seed samples involved were ground using the Laboratory Mill 3600, and a random sample of $0.1 \mathrm{mg}$ was extracted with deionized water. The sample solution was heated to aid extraction, and a sample of $100 \mu \mathrm{l}$ was added to $100 \mathrm{ml}$ of the Glucose (HK) Assay Reagent and then incubated at room temperature for $15 \mathrm{~min}$. A sample blank consisting of 100 and $1000 \mu \mathrm{l}$ deionized water, and a reagent blank with $1000 \mu \mathrm{l}$ of Glucose (HK) Assay Reagent and $100 \mu \mathrm{l}$ of deionized water were used. Samples were read at an absorbance of $340 \mathrm{~nm}$ using the Beckman Coulter DU 800 spectrophotometer in order to determine glucose levels, which were expressed as $\mathrm{mg} \mathrm{g}^{-1} \mathrm{dry}$ weight.

Levels of fructose were measured using the method reported by Bellaloui et al. (2014). Fructose was phosphorylated by ATP using hexokinase, producing fructose 6-phosphate (F6P). The F6P produced was then converted to G6P by phosphoglucose isomerase (PGI), and the P6G then oxidized to 6-phosphogluconate in the presence of NAD in a reaction catalyzed by G6PDH. An equimolar amount of NAD was then reduced to NADH, and the concentration of fructose was measured by the same method as described for glucose.

\section{BORON DETERMINATION}

Concentrations of boron in plant materials were measured using the azomethine-H method described by Lohse (1982) and Dordas et al. (2007), with a detailed description of the protocol reported by Bellaloui et al. (2014). Briefly, a ground sample of $1.0 \mathrm{~g}$ was ashed at $500^{\circ} \mathrm{C}$, extracted with $20 \mathrm{ml}$ of $2 \mathrm{M} \mathrm{HCl}$ at $90^{\circ} \mathrm{C}$ for $10 \mathrm{~min}$, and then a $2 \mathrm{ml}$ sample of the filtered mixture was added to $4 \mathrm{ml}$ of buffer solution (containing 25\% ammonium acetate, $1.5 \%$ EDTA, and $12.5 \%$ acetic acid). A volume of $4 \mathrm{ml}$ of fresh azomethine- $\mathrm{H}$ solution $(0.45 \%$ azomethine- $\mathrm{H}$ and $1 \%$ of ascorbic acid; John et al., 1975) was added. The concentrations of boron in leaves and seeds were determined at $420 \mathrm{~nm}$ using a Beckman
Coulter DU 800 spectrophotometer (Beckman Coulter Inc., Brea, CA, USA).

\section{IRON DETERMINATION}

Iron concentrations in leaves and seeds were determined according to Bandemer and Schaible (1944) and Loeppert and Inskeep (1996). The determination of the concentration was conducted by acid wet digestion, extraction, and reaction of the reduced ferrous Fe with 1,10-phenanthroline, as described by Bellaloui et al. (2011, 2014). Briefly, samples of $2 \mathrm{~g}$ of dried ground leaves and seeds were acid digested, and the soluble constituents were dissolved in $2 \mathrm{M}$ of $\mathrm{HCl}$. A volume of $4 \mathrm{ml}$ of an aliquot containing 1-20 $\mathrm{g} \mathrm{g}$ of iron of the sample solution was transferred into a $25 \mathrm{ml}$ volumetric flask and diluted to $5 \mathrm{ml}$ using $0.4 \mathrm{M} \mathrm{HCl}$. A volume of $1 \mathrm{ml}$ of Quinol solution was added to the $5 \mathrm{ml}$ diluted sample solution and mixed. Three $\mathrm{ml}$ of the phenanthroline solution and $5 \mathrm{ml}$ of the tri-sodium citrate solution $(8 \% \mathrm{w} / \mathrm{v})$ were added. The solution was diluted to $25 \mathrm{ml}$ with distilled water and incubated at room temperature for $4 \mathrm{~h}$. Phenanthroline reagent solution of $0.25 \%$ $(\mathrm{w} / \mathrm{v})$ in $25 \%(\mathrm{v} / \mathrm{v})$ ethanol and quinol solution $(1 \% \mathrm{w} / \mathrm{v})$ was prepared. A standard curve was prepared using a concentration range from 0.0 to $4 \mu \mathrm{g} \mathrm{ml}^{-1}$ of $\mathrm{Fe}$ in $0.4 \mathrm{M} \mathrm{HCl}$, with concentrations measured at an absorbance of $510 \mathrm{~nm}$ using the Beckman Coulter DU 800 spectrophotometer.

\section{PHOSPHORUS DETERMINATION}

The yellow phosphor-vanado-molybdate complex method according to Cavell (1955) was used to determine phosphorus concentrations in leaves and seeds. The detailed description of the method was previously reported by Bellaloui et al. (2009b, 2014). Briefly, dried ground samples of $2 \mathrm{~g}$ of leaves and seed were ashed at $500^{\circ} \mathrm{C}$, and $10 \mathrm{ml}$ of $6 \mathrm{M} \mathrm{HCl}$ were added. The samples were placed in a water bath at $100^{\circ} \mathrm{C}$ to evaporate the solution to dryness. After the extraction of $\mathrm{P}$ using $2 \mathrm{ml}$ of $36 \% \mathrm{v} / \mathrm{v} \mathrm{HCl}$ under heat and filtration, $5 \mathrm{ml}$ of $5 \mathrm{M} \mathrm{HCl}$ and $5 \mathrm{ml}$ of ammonium molybdate-ammonium metavanadate reagent were added to $5 \mathrm{ml}$ of the filtrate. Ammonium molybdate-ammonium metavanadate was prepared by dissolving $25 \mathrm{~g}$ of ammonium molybdate and $1.25 \mathrm{~g}$ of ammonium metavanadate in $500 \mathrm{ml}$ of distilled water. The phosphorus standard curve was established by preparing standard solutions of phosphorus in a range of concentrations from 0 to $50 \mu \mathrm{g} \mathrm{ml}^{-1}$ using dihydrogen orthophosphates. The concentrations of phosphorus were measured at an absorbance of $400 \mathrm{~nm}$ using the Beckman Coulter DU 800 spectrophotometer.

\section{EXPERIMENTAL DESIGN AND STATISTICAL ANALYSIS}

The experimental design was a split-plot in a randomized complete block, with four replicates. A main plot was created for each PD, and subplots were a combination of either a single-row or twinrow planting with a SR of $20,30,40$, or 50 seeds $\mathrm{m}^{-2}$. Replicates within years [rep (year)] and planting date $\times$ rep (year) were considered as components of variance for random effects. Year, PD, and SR were modeled as fixed effects. Residuals of random effect factors as covariance parameters were shown in tables; the residual values refer to Restricted Maximum Residual Likelihood (REML), which reflects the total variance of the random parameters in the model. Analysis of variance of data was performed using PROC 
MIXED in SAS (Statistical Analysis System, Copyright 2002-2010, Cary, NC, USA). Means were separated by Fisher's protected LSD (0.05).

\section{RESULTS}

\section{ANALYSIS OF VARIANCE (ANOVA) OF PLANTING DATE, ROW-TYPE, AND SEEDING RATE IN CLAY SOIL}

In clay soil, ANOVA (Tables $\mathbf{1}$ and 2) showed that year $(\mathrm{Y})$ and $\mathrm{PD}$, and their interactions $(\mathrm{Y} \times \mathrm{PD})$ had significant (ranged from $P \leq 0.05$ to $P \leq 0.0001$ ) effects on protein, oil, and fatty acids. RT had significant effects on protein, oil, stearic, and oleic acid, but not on palmitic, linoleic, and linolenic acids. However, interactions of $\mathrm{PD} \times \mathrm{RT}$ and $\mathrm{Y} \times \mathrm{RT}$ were significant for oil and oleic acid only, indicating that the response of oil and oleic acid to RT and PD were dependent on environmental factors in each year. Palmitic and stearic acids were the least affected by the interactions between Y, PD, and RT. Seeding rate had significant effects on protein, oil, and linoleic acid, while the interactions between SR, PD, and RT were significant for protein, oleic and linolenic acid. This indicated that the influence of SR on seed constituents was dependent on PD and RT. Based on this, the most sensitive constituents to agronomic practices and seasonal environmental factors were protein, oil, and oleic acid, and the least sensitive constituents to agronomic practices and environment were palmitic and stearic acids. Linoleic and linolenic acids were in between. The level of interactions between $\mathrm{Y}, \mathrm{PD}, \mathrm{RT}$, and $\mathrm{SR}$ for seed composition ranged from $P \leq 0.05$ to $P \leq 0.0001$, depending on the seed constituent, indicating the different sensitivity of seed composition constituents to environments and agricultural practices (Tables 1 and 2). Except for raffinose, sugars and mineral concentrations were significantly influenced by $\mathrm{Y}$ and $\mathrm{PD}$. However, $\mathrm{Y} \times \mathrm{PD}$ interactions were significant for B, P, and all sugars, except for stachyose. RT was significant for raffinose, glucose, fructose, $B$ and $P$, while $S R$ was significant for all minerals, and the sugars sucrose, raffinose, and glucose. Interactions between Y, PD, RT, and SR influenced some constituents. However, the least influenced constituent to agricultural practices was stachyose, while the most influenced constituents were the minerals (B, P, and Fe). Since Y interacted with other factors for some seed constituents, results were presented by year (Bellaloui et al., 2009b, 2010, 2011).

\section{ANALYSIS OF VARIANCE OF PLANTING DATE, ROW-TYPE, AND SEEDING RATE IN SANDY SOIL}

In sandy soil, $\mathrm{Y}, \mathrm{PD}$, and their interactions $(\mathrm{Y} \times \mathrm{PD})$ were significant (ranged from $P \leq 0.05$ to $P \leq 0.0001$ ) for protein, oil, and fatty acids, indicating that both Y and PD had different effects on these constituents, depending on the environmental factors in each year (Table 3). RT significantly interacted with $\mathrm{Y}$ and PD for the seed protein, oil, and palmitic acid, indicating that RT effects were dependent on Y and PD. However, RT on its own had no significant effects on these constituents. SR had significant effects on oil, oleic and linolenic acids, but its interaction $(\mathrm{Y} \times \mathrm{SR})$ had significant effects on protein, oil, oleic, and linolenic acid. It can be concluded that under sandy soil conditions the most responsive constituents to agronomic practices and environment were protein, oil, and oleic acid, while the least responsive constituents

Table 1 | Analysis of variance ( $F$ and $P$ values) of seed protein, oil, fatty acids $\left(\mathrm{g} \mathrm{kg}^{-1}\right)$ in soybean as influenced by year $(\mathrm{Y})$, seeding rate (SR), planting date (PD), and row-type (RT, single- or twin-row) in Sharkey clay soil in 2009 and 2010 at Stoneville, MS, USA.

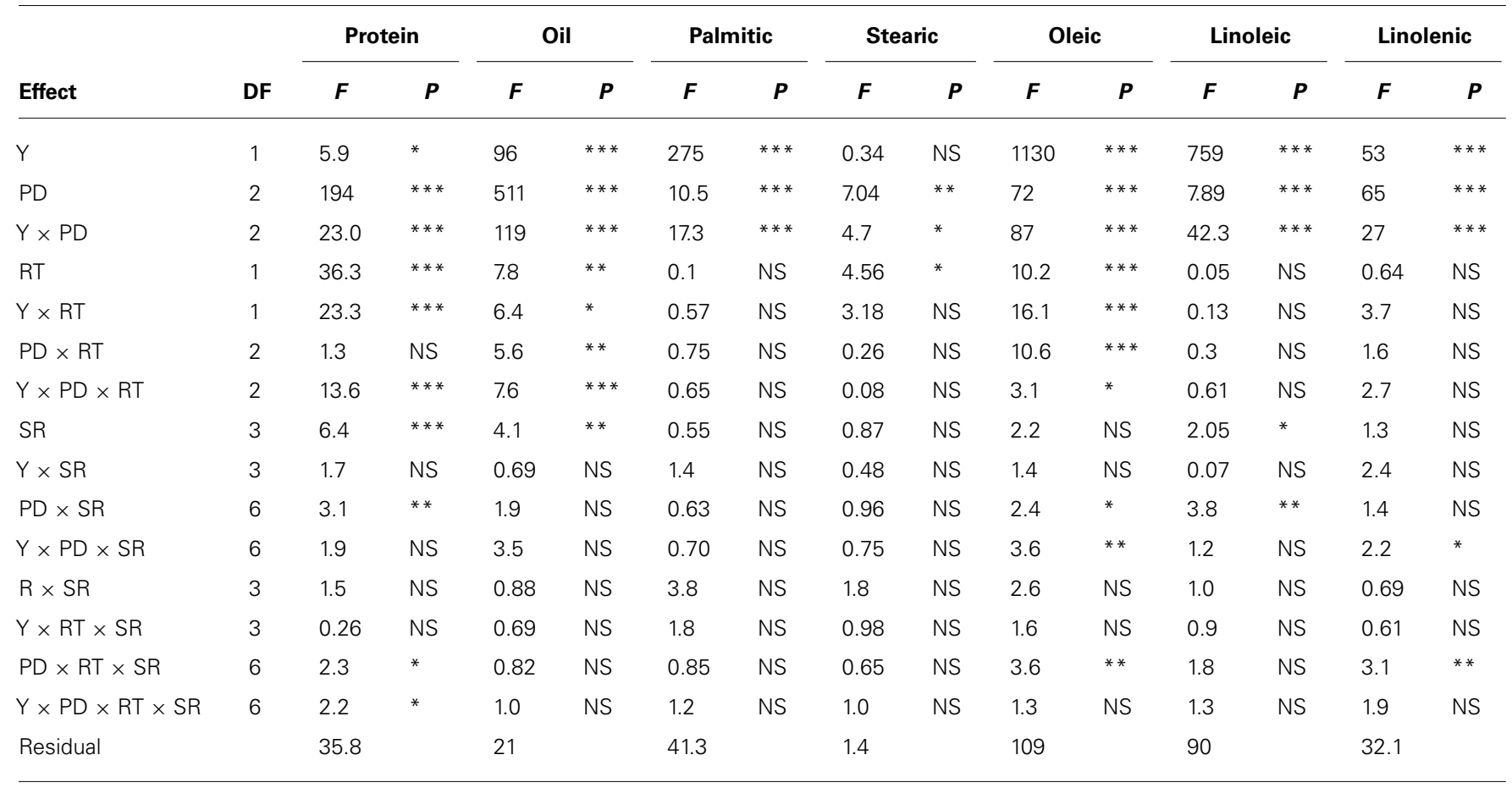

${ }^{*} P \leq 0.05 ;{ }^{*} P \leq 0.01 ;{ }^{*}{ }^{*} P \leq 0.001 ; N S$, not significant. 
Table 2 | Analysis of variance ( $F$ and $P$ values) of sucrose, raffinose, stachyose, glucose, fructose $\left(\mathrm{mg} \mathrm{g}^{-1}\right)$, boron $\left(B, \mathrm{mg} \mathrm{kg}^{-1}\right)$, phosphorus $(P, \mathrm{~g}$ $\mathrm{kg}^{-1}$ ), and iron ( $\mathrm{Fe}, \mathrm{mg} \mathrm{kg}^{-1}$ ) in soybean as influenced by year (Y), seeding rate (SR), planting date (PD), and row-type (RT, single- or twin-row) in Sharkey clay soil in 2009 and 2010 at Stoneville, MS, USA.

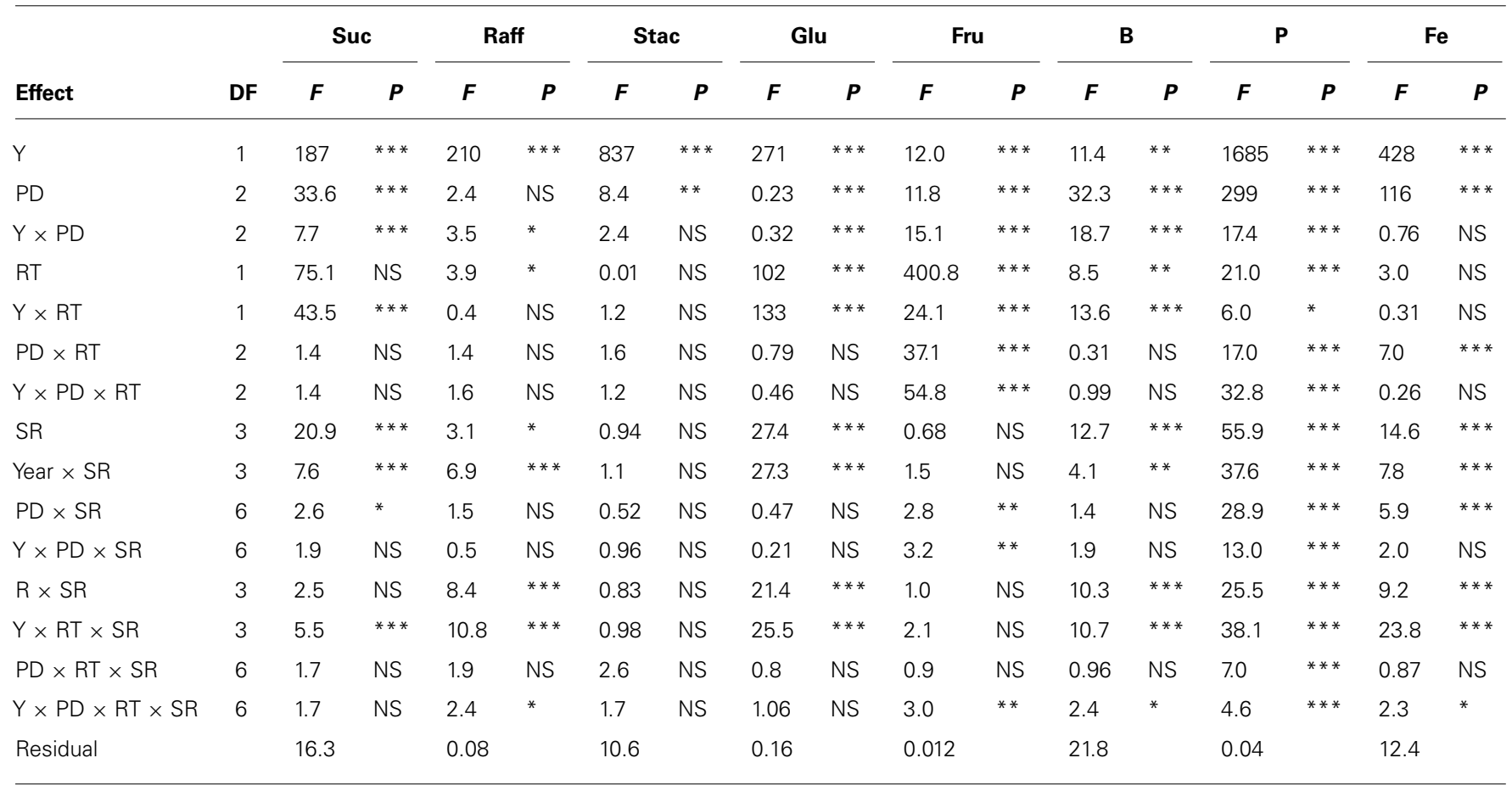

${ }^{*} P \leq 0.05 ;{ }^{*} P \leq 0.01 ;{ }^{*}{ }^{*} P \leq 0.001 ; N S$, not significant, suc, sucrose; raff, raffinose; stac, stachyose; glu, glucose; and fruc, fructose.

Table 3 | Analysis of variance ( $F$ and $P$ values) of seed protein, oil, fatty acids $\left(\mathrm{g} \mathrm{kg}^{-1}\right)$ in soybean as influenced by year (Y), seeding rate (SR), planting date (PD), and row-type (RT, single- or twin- row) in Beulah fine sandy loam soil in 2009 and 2010 at Stoneville, MS, USA.

\begin{tabular}{|c|c|c|c|c|c|c|c|c|c|c|c|c|c|c|c|}
\hline \multirow{2}{*}{$\begin{array}{l}\text { Effect } \\
Y\end{array}$} & \multirow{2}{*}{$\frac{\text { DF }}{1}$} & \multicolumn{2}{|c|}{ Protein } & \multicolumn{2}{|c|}{ Oil } & \multicolumn{2}{|c|}{ Palmitic } & \multicolumn{2}{|c|}{ Stearic } & \multicolumn{2}{|c|}{ Oleic } & \multicolumn{2}{|c|}{ Linoleic } & \multicolumn{2}{|c|}{ Linolenic } \\
\hline & & 240 & $* * *$ & 328 & $* * *$ & 14.4 & $* *$ & 33.1 & $* *$ & 300 & $* * *$ & 454 & $* * *$ & 226 & $* * *$ \\
\hline PD & 2 & 105 & $* * *$ & 123 & $* * *$ & 243 & $* * *$ & 37.9 & $* * *$ & 4.95 & * & 64.1 & $* * *$ & 0.59 & NS \\
\hline$Y \times P D$ & 2 & 82.1 & $* * *$ & 68.3 & $* * *$ & 54.1 & $* * *$ & 21.4 & $* * *$ & 23 & $* * *$ & 40.9 & $* * *$ & 3.3 & * \\
\hline $\mathrm{RT}$ & 1 & 0.01 & NS & 0.07 & NS & 0.26 & NS & 0.05 & NS & 2.3 & NS & 2.46 & NS & 0.04 & NS \\
\hline $\mathrm{Y} \times \mathrm{RT}$ & 1 & 10.1 & $* *$ & 0.14 & NS & 17.3 & $* * *$ & 0.18 & NS & 1.4 & NS & 0.24 & NS & 0.14 & NS \\
\hline$Y \times P D \times R T$ & 2 & 1.9 & NS & 10.3 & $* * *$ & 15.4 & $* * *$ & 0.52 & NS & 1.3 & NS & 0.7 & NS & 0.57 & NS \\
\hline SR & 3 & 0.24 & NS & 14.8 & $* * *$ & 1.3 & NS & 0.51 & NS & 28.9 & $* * *$ & 0.15 & NS & 27.7 & $* * *$ \\
\hline Year $\times$ SR & 3 & 3.7 & $* *$ & 6.3 & $* *$ & 0.79 & NS & 1.17 & NS & 30.1 & $* * *$ & 0.18 & NS & 31.9 & $* * *$ \\
\hline $\mathrm{PD} \times \mathrm{SR}$ & 6 & 2.4 & * & 12.2 & $* * *$ & 3.2 & $* *$ & 0.81 & NS & 2.1 & NS & 0.52 & NS & 1.3 & NS \\
\hline $\mathrm{Y} \times \mathrm{PD} \times \mathrm{SR}$ & 6 & 2.5 & * & 17.4 & $* * *$ & 4.4 & $* *$ & 1.01 & NS & 1.6 & NS & 0.48 & NS & 1.6 & NS \\
\hline $\mathrm{Y} \times \mathrm{PD} \times \mathrm{RT} \times \mathrm{SR}$ & 6 & 5.53 & $* * *$ & 3.4 & $* *$ & 1.94 & NS & 0.8 & NS & 3.23 & $* *$ & 0.43 & NS & 0.35 & NS \\
\hline Residual & & 53.6 & & 28.1 & & 29.6 & & 1.92 & & 155 & & 161 & & 38.1 & $* * *$ \\
\hline
\end{tabular}

${ }^{*} P \leq 0.05 ;{ }^{*} P \leq 0.01 ;{ }^{*}{ }^{*} P \leq 0.001 ; N S$, not significant. 
were stearic, linoleic, and linolenic acids. Sugars, except glucose, were significantly influenced by both Y and PD (Table 4); however, interaction with $Y$ did not affect sucrose, raffinose, or glucose. This showed that these sugars had the same response pattern in each year. Year, PD, and their interactions had significant effects on all minerals, indicating that these mineral levels were influenced by $\mathrm{PD}$, but this influence is also affected by yearly environmental factors. RT had significant effects on all sugars (except glucose) and minerals, and its interaction with Y or PD was mainly significant for minerals. Sucrose, fructose, B and $\mathrm{P}$ were the constituents most influenced by SR and its interactions with Y and PD, reflecting the different response of seed constituents to agricultural practices such as PD, SR, and RT. It can be concluded that the least responsive constituents were stachyose, and glucose, and the most responsive were sucrose, fructose, and minerals (B, $\mathrm{P}$, and $\mathrm{Fe}$ ). Since $\mathrm{Y}$ interacted with other factors for some seed constituents, results were presented by year (Bellaloui et al., 2009b, 2010, 2011).

\section{EFFECTS OF PLANTING DATE, SEEDING RATE, AND ROW-TYPE ON SEED COMPOSITION IN CLAY SOIL}

Mean values in 2009 in clay soil and in April planting (Table 5) showed that protein concentrations decreased with increasing SR on single-rows, but increased on twin-rows. On the single-rows, the linolenic acid was reduced with SR, but remained constant or not consistent on the twin-rows. Oleic acid, sucrose, $\mathrm{P}$, and $\mathrm{B}$ increased with increasing SR, but this increase continued only until a maximum concentration reached, after which the concentration deceased or remained constant. No consistent effects of SR increase were observed for the other seed constituents. A similar pattern was observed for $\mathrm{B}$ and $\mathrm{P}$ in May and June plantings on single- and twin-rows. However, for these PDs protein concentration increased with SR on single-row, but decreased on twin-row (Table 5). Linolenic acid increased with SR and then decreased at higher SR on single- and twin-rows. In May planting the concentrations of oil and minerals increased with SR increases on single- and twin-rows, but the pattern of oleic and protein varied, depending on RT. Generally, protein was higher in May and June plantings than in April planting, but oil concentration had the opposite trend, higher in April and lower in May and June plantings on single- or twin-rows. In 2010, except in May planting, protein, glucose, $\mathrm{B}$, and Fe concentrations increased with SR increase in April and June plantings (Table 6) on single- and twinrows. Protein was higher in May planting and oil was higher in April planting on single- and twin-rows, confirming the observation in 2009. Oleic acid was higher in 2010 than in 2009 for all PDs and on single- and twin-rows.

\section{EFFECTS OF PLANTING DATE, SEEDING RATE, AND ROW-TYPE ON SEED COMPOSITION IN SANDY SOIL}

Mean values in 2009 (Table 7) showed that in April planting on single-rows, oleic acid decreased and linolenic acid and minerals increased with increasing SR until the maximum concentration was achieved, after which the concentrations either became constant or declined. On twin-rows, protein, linolenic acid, sucrose, $\mathrm{B}$, and $\mathrm{P}$ concentrations increased with increasing SR, and oleic acid and stachyose decreased. In May planting, protein, oil,

Table 4 | Analysis of variance ( $F$ and $P$ values) of sucrose, raffinose, stachyose, glucose, fructose $\left(\mathrm{mg} \mathrm{g}^{-1}\right)$, and boron $\left(B, \mathrm{mg} \mathrm{kg}^{-1}\right)$, phosphorus $(P$, $\mathrm{g} \mathrm{kg}^{-1}$ ), and iron (Fe, $\mathrm{mg} \mathrm{kg}^{-1}$ ) in soybean as influenced by year (Y), seeding rate (SR), planting date (PD), and row-type (RT, single- or twin-row) in Beulah fine sandy loam soil in 2009 and 2010 at Stoneville, MS, USA.

\begin{tabular}{|c|c|c|c|c|c|c|c|c|c|c|c|c|c|c|c|c|c|}
\hline \multirow[b]{2}{*}{ Effect } & \multirow[b]{2}{*}{ DF } & \multicolumn{2}{|c|}{ Suc } & \multicolumn{2}{|c|}{ Raff } & \multicolumn{2}{|c|}{ Stac } & \multicolumn{2}{|c|}{ Glu } & \multicolumn{2}{|c|}{ Fru } & \multicolumn{2}{|c|}{ B } & \multicolumn{2}{|c|}{$\mathbf{P}$} & \multicolumn{2}{|c|}{ B } \\
\hline & & $F$ & $P$ & $\boldsymbol{F}$ & $\boldsymbol{P}$ & $\boldsymbol{F}$ & $P$ & $\boldsymbol{F}$ & $P$ & $\boldsymbol{F}$ & $P$ & $\boldsymbol{F}$ & $P$ & $\boldsymbol{F}$ & $P$ & $F$ & $\boldsymbol{P}$ \\
\hline Y & 1 & 500. & $* * *$ & 374 & $* * *$ & 153 & *** & 665 & $* * *$ & 5216 & *** & 442 & $* * *$ & 1044 & $* * *$ & 489 & $* * *$ \\
\hline PD & 2 & 13.8 & ** & 14.3 & $* *$ & 12.8 & $* *$ & 0.02 & NS & 22.41 & $* * *$ & 75.6 & *** & 79.9 & $* * *$ & 9.2 & ** \\
\hline$Y \times P D$ & 2 & 2.59 & NS & 2.3 & NS & 6.58 & $* *$ & 0.5 & NS & 2.71 & NS & 44.0 & $* * *$ & 79.75 & $* * *$ & 9.7 & $* *$ \\
\hline $\mathrm{RT}$ & 1 & 132 & $* * *$ & 23.6 & $* * *$ & 12.5 & $* *$ & 669 & NS & 407 & *** & 150 & $* * *$ & 162 & $* * *$ & 132 & $* * *$ \\
\hline$Y \times R T$ & 1 & 2.9 & NS & 57.6 & $* * *$ & 0.4 & NS & 2.26 & NS & 28.8 & *** & 7.17 & $* *$ & 28.6 & $* * *$ & 54.7 & $* * *$ \\
\hline$P D \times R T$ & 2 & 2.3 & NS & 1.47 & NS & 0.07 & NS & 0.56 & NS & 64.0 & $* * *$ & 2.79 & NS & 19.3 & $* * *$ & 17.8 & *** \\
\hline$Y \times P D \times R T$ & 2 & 1.3 & NS & 0.1 & NS & 1.86 & NS & 1.46 & NS & 26.8 & $* * *$ & 0.92 & NS & 17.8 & $* * *$ & 14.2 & $* * *$ \\
\hline SR & 3 & 8.6 & $* * *$ & 0.72 & NS & 0.61 & NS & 1.4 & NS & 5.41 & $* *$ & 54.7 & $* * *$ & 65.3 & $* * *$ & 1.06 & NS \\
\hline Year $\times$ SR & 3 & 2.6 & $*$ & 0.89 & NS & 0.86 & NS & 0.0 & NS & 0.0 & NS & 0.0 & NS & 0.0 & NS & 0.29 & NS \\
\hline $\mathrm{PD} \times \mathrm{SR}$ & 6 & 3.5 & * * & 5.5 & $* * *$ & 0.59 & NS & 0.38 & NS & 5.1 & *** & 22.91 & $* * *$ & 31.0 & $* * *$ & 2.8 & $* *$ \\
\hline$Y \times P D \times S R$ & 6 & 1.5 & NS & 2.29 & * & 0.45 & NS & 0.41 & NS & 6.9 & $* * *$ & 18.75 & $* * *$ & 61.4 & $* * *$ & 4.93 & *** \\
\hline$R \times S R$ & 3 & 3.6 & NS & 0.44 & NS & 0.88 & NS & 0.87 & NS & 5.1 & $* *$ & 12.48 & $* * *$ & 88.5 & $* * *$ & 6.8 & $* *$ \\
\hline $\mathrm{Y} \times \mathrm{RT} \times \mathrm{SR}$ & 3 & 0.7 & NS & 0.54 & NS & 1.27 & NS & 0.0 & NS & 0.0 & NS & 0.0 & NS & 0.03 & NS & 2.5 & NS \\
\hline $\mathrm{PD} \times \mathrm{RT} \times \mathrm{SR}$ & 6 & 3.87 & ** & 4.53 & $* *$ & 1.9 & NS & 0.86 & NS & 11.6 & $* * *$ & 0.93 & NS & 9.6 & $* * *$ & 17.5 & $* * *$ \\
\hline$Y \times P D \times R T \times S R$ & 6 & 5.1 & $* * *$ & 5.6 & $* * *$ & 0.27 & NS & 0.62 & NS & 17.4 & $* * *$ & 0.52 & NS & 12.2 & $* * *$ & 4.9 & $* *$ \\
\hline Residual & & 20 & & 0.25 & & 13.9 & & 0.14 & & 0.01 & & 9 & & 0.06 & & 12.8 & \\
\hline
\end{tabular}

${ }^{*} P \leq 0.05 ;{ }^{*} P \leq 0.01 ; * * * P \leq 0.001 ; N S$, not significant; suc, sucrose, raff, raffinose; stac, stachyose; glu, glucose; and fruc, fructose. 
Table 5 | Effects of row-type (RT, single, $\mathrm{S}$ or twin, $\mathrm{T})$, seeding rate (SR, seed $\left.\mathrm{m}^{-2}\right)$, and planting date on seed protein, oil, fatty acids (g kg $\left.\mathbf{~}^{-1}\right)$, sucrose (Suc), stachyose (Stac), glucose (Glu) $\left(\mathrm{mg} \mathrm{g}^{-1}\right)$, boron $\left(B, \mathrm{mg} \mathrm{kg}^{-1}\right)$, phosphorus $\left(\mathrm{P}, \mathrm{g} \mathrm{kg}^{-1}\right)$, and iron $\left(\mathrm{Fe}\right.$, $\left.\mathrm{mg} \mathrm{kg}^{-1}\right)$ in soybean in Sharkey clay soil in 2009 at Stoneville, MS, USA.

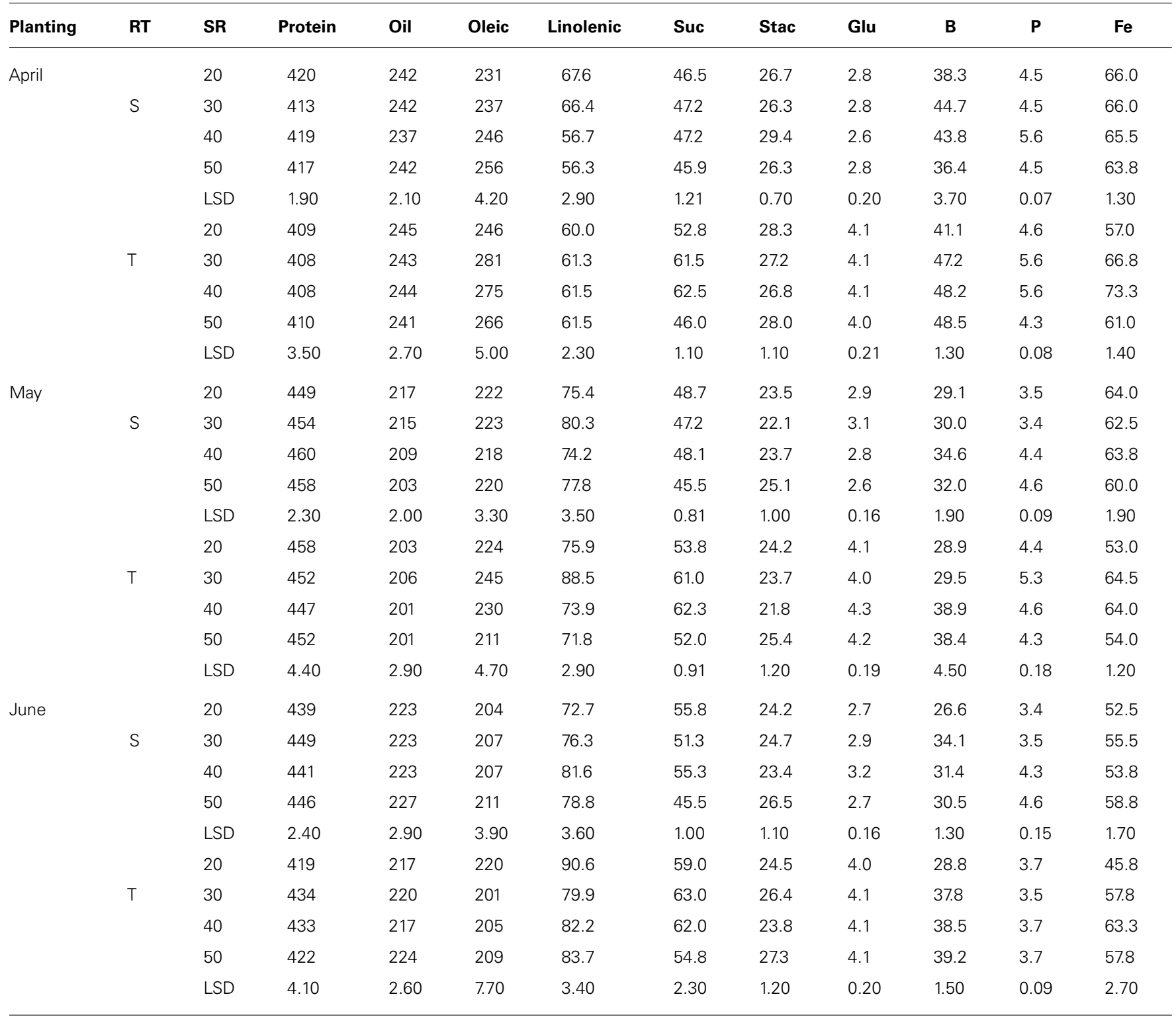

Means were separated by Fisher's least significant difference LSD (0.05).

linolenic acid, B, and $\mathrm{P}$ increased with increasing SR on singlerows. On twin-rows, linolenic acid, sucrose, glucose, $\mathrm{B}$, and $\mathrm{P}$ concentrations increased, and protein and oleic acid concentrations decreased. In June planting on single-rows, linolenic acid, glucose, B, P, and Fe concentrations increased with increasing SR, but oleic acid decreased. On twin-rows, oleic acid decreased and linolenic acid, sucrose, and B concentrations increased. Protein was higher in June planting, but oil was higher in April planting. In 2010 (Table 8) in April planting, sucrose and Fe concentrations increased with increasing SR on single- and twinrows. In May planting, protein concentration decreased with SR, but oil concentration and B concentrations increased. In June planting, protein, $\mathrm{P}$, and $\mathrm{Fe}$ increased and oil and oleic acid decreased with SR on single- and twin-rows. Sucrose and B concentrations showed a pattern of increase with increasing SR on twin-rows.

\section{SOIL AND LEAF NUTRIENTS LEVELS}

Soil analyses showed that in clay soil, the average nutrient levels in 2009 and 2010, respectively, were: $\mathrm{C}=1.40$ and $1.10 \%$; $\mathrm{N}=0.13$ and $0.10 \% ; \mathrm{S}=31.2$ and $30.9 \mathrm{mg} \mathrm{kg}^{-1} ; \mathrm{K}=2340$ and $2570 \mathrm{mg} \mathrm{kg}^{-1} ; \mathrm{P}=355$ and $368 \mathrm{mg} \mathrm{kg}^{-1} ; \mathrm{B}=2.45$ and $2.92 \mathrm{mg} \mathrm{kg}^{-1}$; and $\mathrm{Fe}=20.13$ and $22.91 \mathrm{~g} \mathrm{~kg}^{-1}$. In sandy soil, the average nutrient levels, respectively, in 2009 and 2010 were: $\mathrm{C}=1.10$ and $1.30 \% ; \mathrm{N}=0.10$ and $0.11 \% ; \mathrm{S}=28.7$ and $30.1 \mathrm{mg} \mathrm{kg}^{-1} ; \mathrm{K}=2140$ and $2060 \mathrm{mg} \mathrm{kg}^{-1} ; \mathrm{P}=267$ and 
Table 6 | Effects of row-type (RT, single, $\mathrm{S}$ or twin, T), seeding rate (SR, seed $\left.\mathrm{m}^{-2}\right)$, and planting date on seed protein, oil, fatty acids $\left(\mathrm{g} \mathbf{k g}^{-1}\right)$, sucrose (Suc), stachyose (Stac), glucose (Glu) $\left(\mathrm{mg} \mathrm{g}^{-1}\right)$, boron $\left(B, \mathrm{mg} \mathrm{kg}^{-1}\right)$, phosphorus $\left(\mathrm{P}, \mathrm{g} \mathrm{kg}^{-1}\right)$, and iron $\left(\mathrm{Fe}, \mathrm{mg} \mathrm{kg}^{-1}\right)$ in soybean in Sharkey clay soil in $\mathbf{2 0 1 0}$ at Stoneville, MS, USA.

\begin{tabular}{|c|c|c|c|c|c|c|c|c|c|c|c|c|}
\hline Planting & RT & SR & Protein & Oil & Oleic & Linolenic & Suc & Stac & Glu & B & $\mathbf{P}$ & $\mathrm{Fe}$ \\
\hline \multirow[t]{9}{*}{ April } & & 20 & 419 & 231 & 279 & 66.3 & 23.8 & 38.3 & 1.6 & 28.1 & 3.6 & 47.8 \\
\hline & $S$ & 30 & 424 & 227 & 276 & 62.5 & 23.3 & 39.3 & 1.8 & 36.8 & 3.4 & 57.0 \\
\hline & & 40 & 421 & 230 & 282 & 60.7 & 23.8 & 42.3 & 2.6 & 33.9 & 3.5 & 52.8 \\
\hline & & 50 & 423 & 228 & 275 & 69.7 & 25.3 & 42.8 & 3.4 & 42.1 & 3.4 & 57.3 \\
\hline & & LSD & 2.80 & 1.90 & 4.70 & 2.40 & 3.40 & 2.20 & 0.21 & 1.30 & 0.10 & 1.40 \\
\hline & $\mathrm{T}$ & 30 & 423 & 226 & 289 & 64.2 & 21.5 & 44.3 & 2.0 & 27.0 & 3.4 & 53.0 \\
\hline & & 40 & 421 & 230 & 270 & 63.8 & 24.0 & 40.8 & 3.4 & 45.3 & 3.4 & 55.5 \\
\hline & & 50 & 421 & 228 & 284 & 66.1 & 22.0 & 40.5 & 2.3 & 30.5 & 3.3 & 55.0 \\
\hline & & LSD & 2.60 & 1.90 & 4.90 & 2.40 & 2.90 & 1.70 & 0.30 & 5.00 & 0.05 & 1.30 \\
\hline \multirow{7}{*}{ May } & & 50 & 443 & 212 & 289 & 70.7 & 27.5 & 40.3 & 3.8 & 34.3 & 3.4 & 52.5 \\
\hline & & LSD & 2.41 & 1.50 & 5.60 & 2.80 & 1.80 & 2.00 & 0.14 & 1.20 & 0.13 & 1.50 \\
\hline & & 20 & 437 & 217 & 278 & 68.5 & 33.3 & 37.5 & 1.9 & 36.8 & 3.4 & 56.0 \\
\hline & $\mathrm{T}$ & 30 & 438 & 215 & 287 & 66.8 & 24.5 & 37.8 & 1.9 & 26.3 & 2.3 & 44.0 \\
\hline & & 40 & 437 & 216 & 284 & 68.2 & 34.3 & 38.3 & 3.7 & 35.3 & 3.3 & 54.0 \\
\hline & & 50 & 440 & 216 & 282 & 65.5 & 33.5 & 42.0 & 1.7 & 35.5 & 3.4 & 43.5 \\
\hline & & LSD & 2.20 & 1.70 & 7.60 & 2.40 & 1.60 & 1.90 & 0.19 & & 0.07 & 1.50 \\
\hline \multirow[t]{4}{*}{ June } & & 20 & 419 & 210 & 286 & 72.4 & 35.3 & 42.3 & 1.8 & 29.6 & 2.4 & 41.5 \\
\hline & $S$ & 30 & 431 & 213 & 295 & 66.8 & 29.3 & 40.3 & 1.6 & 36.8 & 2.5 & 43.8 \\
\hline & & 50 & 437 & 203 & 278 & 67.5 & 24.8 & 38.8 & 1.7 & 39.3 & 3.5 & 47.0 \\
\hline & & LSD & 2.60 & 2.10 & 2.80 & 2.60 & 2.70 & 2.40 & 2.19 & 1.60 & 0.11 & 1.40 \\
\hline
\end{tabular}

Means were separated by Fisher's least significant difference LSD (0.05).

$284 \mathrm{mg} \mathrm{kg}^{-1} ; \mathrm{B}=1.20$ and $1.60 \mathrm{mg} \mathrm{kg}^{-1}$; and $\mathrm{Fe}=18.72$ and $18.89 \mathrm{~g} \mathrm{~kg}^{-1}$. Nutrient concentrations in leaf samples in clay soil, respectively in 2009 and 2010 were: $\mathrm{N}=5.20$ and $4.11 \%$; $\mathrm{S}=0.31$ and $0.27 \% ; \mathrm{K}=2000$ and $1570 \mathrm{mg} \mathrm{kg}^{-1} ; \mathrm{P}=390$ and $230 \mathrm{mg} \mathrm{kg}^{-1} ; \mathrm{B}=40.56$ and $33.76 \mathrm{mg} \mathrm{kg}^{-1}$; and $\mathrm{Fe}=209$ and $86 \mathrm{mg} \mathrm{kg}^{-1}$. Nutrient concentrations in leaves in sandy loam soil, respectively in 2009 and 2010, were: $\mathrm{N}=4.80$ and $4.76 \% ; \mathrm{S}=0.37$ and $0.23 \% ; \mathrm{K}=2.20$ and $1.43 \% ; \mathrm{P}=0.41$ and $0.29 \% ; \mathrm{B}=35.7$ and $28.70 \mathrm{mg} \mathrm{kg}^{-1}$; and $\mathrm{Fe}=157$ and $94.50 \mathrm{mg} \mathrm{kg}^{-1}$. The analysis of random samples of fully expanded leaves taken across the field at R5 to R6 showed adequate concentrations of nutrients in soybean grown in both sites. It was noticed that concentrations of nutrients, especially for K, B, P, and Fe, in 2009 were greater than in 2010 and this observation was attributed to heat and drier conditions in 2010.

\section{DISCUSSION}

EFFECTS OF PLANTING DATE, SEEDING RATE, AND ROW-TYPE ON SEED COMPOSITION

The current research showed that April planting (early planting) resulted in higher oil, oleic acid, sucrose, and minerals, especially $\mathrm{B}$ and $\mathrm{P}$, on both single and twin-rows, and June planting (late planting) resulted in higher protein and linolenic acid, but lower oleic acid and oil concentrations in 2009 and 2010. Previous research showed that the response of seed constituents to PD was mainly due to temperature differences (Dardanelli et al., 
Table 7 | Effects of row-type (RT, single, $S$ or twin, $T)$, seeding rate (SR, seed $\left.\mathbf{~}^{-2}\right)$, and planting date on seed protein, oil, fatty acids $\left(\mathrm{g} \mathrm{kg}^{-1}\right)$, sucrose (Suc), stachyose (Stac), glucose (Glu) $\left(\mathrm{mg} \mathrm{g}^{-1}\right)$, boron $\left(B, \mathrm{mg} \mathrm{kg}^{-1}\right)$, phosphorus $\left(\mathrm{P}_{\mathrm{g} \mathrm{kg}} \mathrm{g}^{-1}\right)$, and iron $\left(\mathrm{Fe}, \mathrm{mg} \mathrm{kg}^{-1}\right)$ in soybean in Beulah fine sandy loam soil in 2009 at Stoneville, MS, USA.

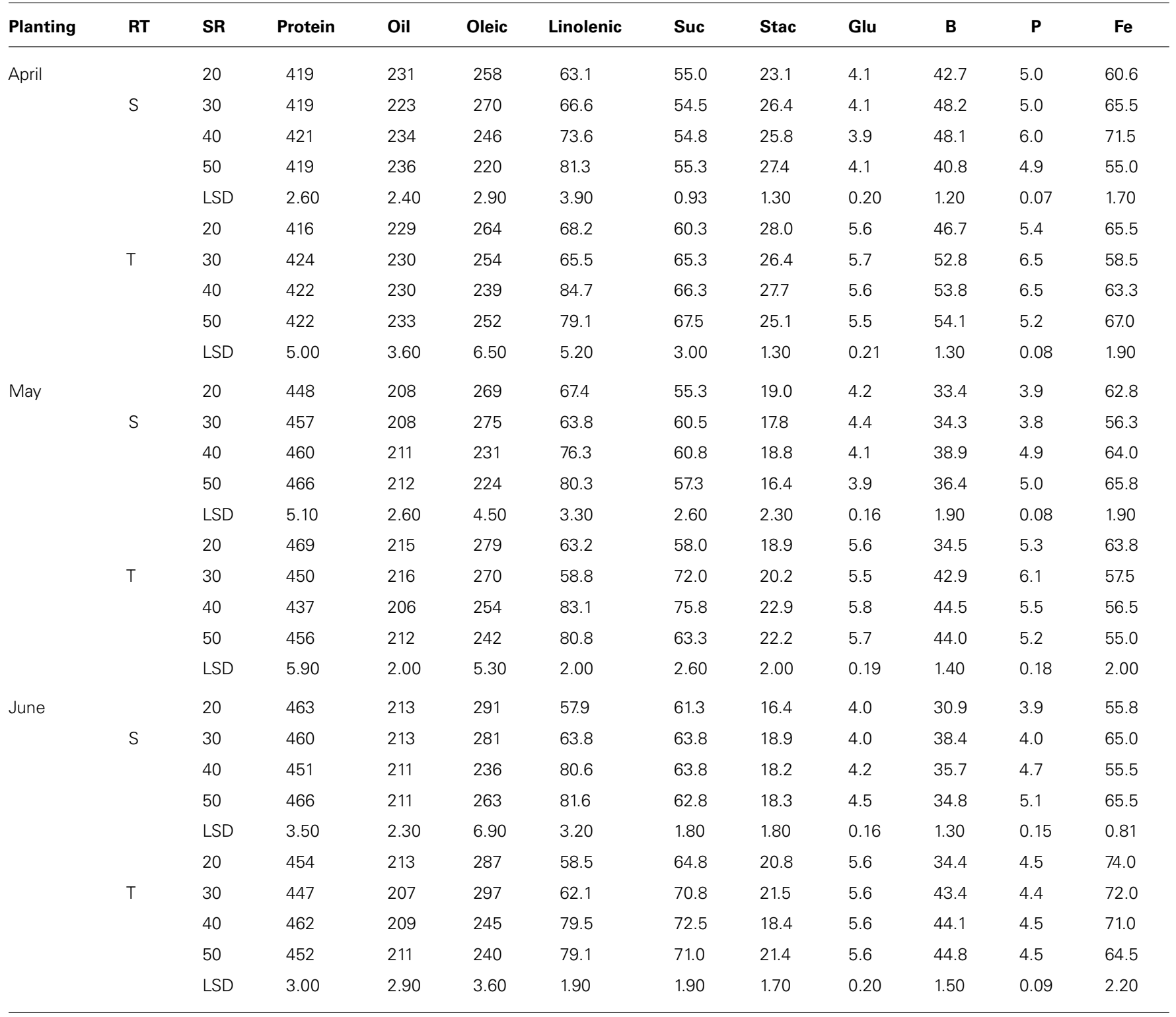

Means were separated by Fisher's least significant difference LSD (0.05). Suc, sucrose; stac, stachyose, and glu, glucose.

2006; Bellaloui et al., 2009b) or other environmental factors such as drought (Piper and Boote, 1999; Bellaloui et al., 2009b, 2014). Dardanelli et al. (2006) investigated the consistency of soybean MG effects and their interactions with the environment on protein and oil, and found that environment was mainly defined by PD and location, and that environment was the most important source of variation for protein and oil. Previous research on the effects of PD on seed composition is still inconsistent and inconclusive. For example, oil concentration increased with early planting, but this increase pattern was not consistent across locations (Helms et al., 1990; Kane et al., 1997; Pedersen and Lauer, 2004), indicating that the response of seed constituents to PDs depends on the environment under which soybeans are grown.
Our research showed that late planting (June planting) resulted in the increase of protein concentration and decrease in oil concentration, partially agreeing with those of Helms et al. (1990) and Pedersen and Lauer (2004). The high oleic acid and low linolenic acid concentrations in the early planting (April planting), and the low oleic acid and high linolenic acid in late planting, especially the June planting, could be due to the inverse relationship between these two constituents (Carver et al., 1986; Dornbos and Mullen, 1992; Bellaloui et al., 2009b) and temperature differences. Studying high oleic acid gemplasm lines, it was suggested that the instability of oleic acid across environments was due mainly to temperature effects on enzymes controlling biosynthesis of soybean seed fatty acids, especially during seed-fill (R5 to R6) stage 
Table 8 | Effects of row-type (RT, single, $\mathrm{S}$ or twin, $\mathrm{T})$, seeding rate (SR, seed $\left.\mathrm{m}^{-2}\right)$, and planting date on seed protein, oil, fatty acids $\left(\mathrm{g} \mathbf{k g}^{-1}\right)$, sucrose (Suc), stachyose (Stac), glucose (Glu) $\left(\mathrm{mg} \mathrm{g}^{-1}\right)$, boron $\left(B, \mathrm{mg} \mathrm{kg}^{-1}\right)$, phosphorus $\left(\mathrm{P}, \mathrm{g} \mathrm{kg}^{-1}\right)$, and iron $\left(\mathrm{Fe}\right.$, $\left.\mathrm{mg} \mathrm{kg}^{-1}\right)$ in soybean in Beulah fine sandy loam soil in $\mathbf{2 0 1 0}$ at Stoneville, MS, USA.

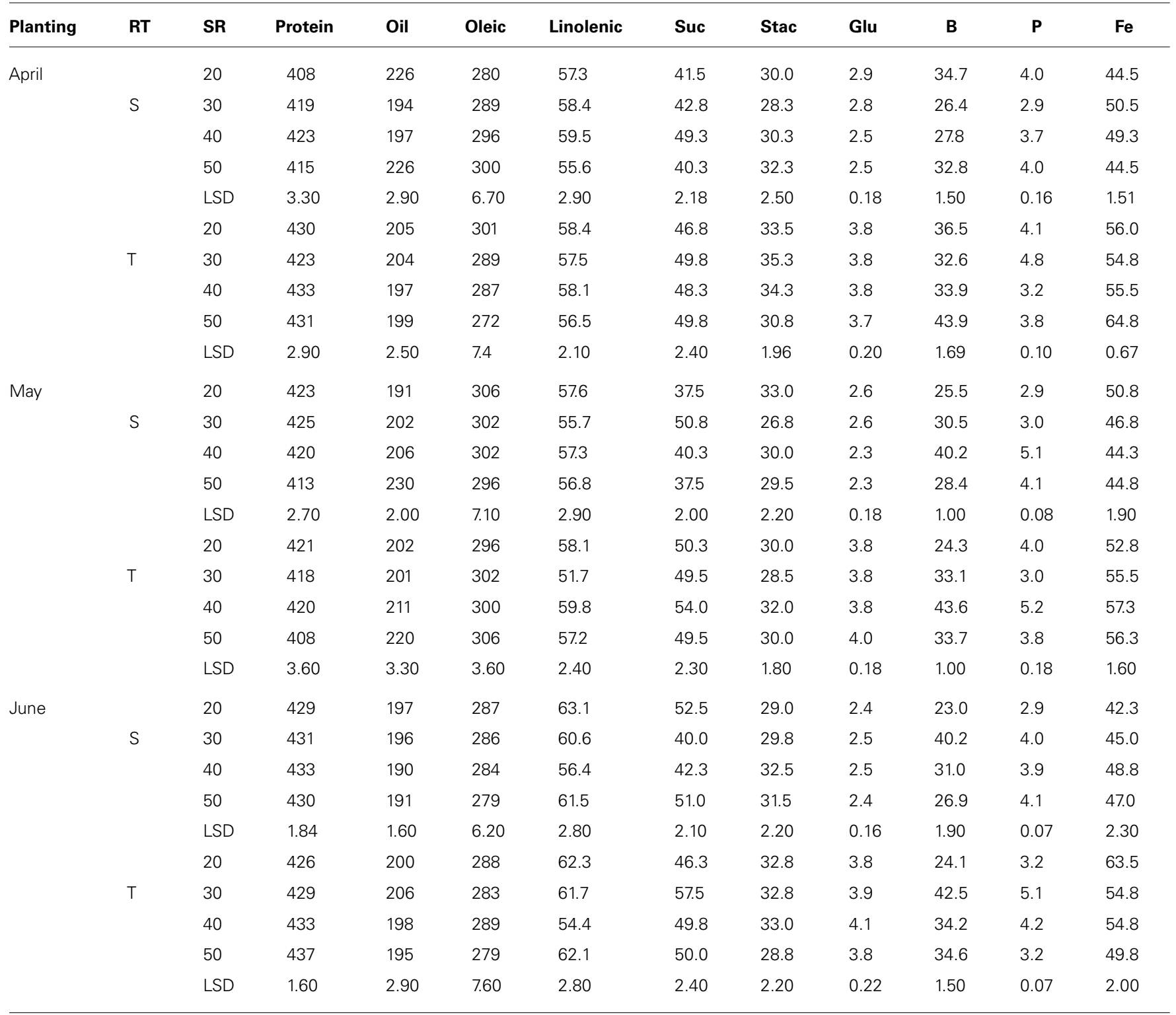

Means were separated by Fisher's least significant difference LSD (0.05). Suc, sucrose; stac, stachyose; and glu, glucose.

(Howell and Collins, 1957; Wilcox and Cavins, 1992; Bachlava and Cardinal, 2009). Bachlava and Cardinal (2009) suggested that the late planting may result in a decrease of linolenic and palmitic acids, but stearic acid may increase, and the changes in fatty acids with late planting may be due to temperature changes during seed maturation at later planting (Wilcox and Cavins, 1992). Other researchers showed that high oleic and low linolenic acids under warmer conditions (Carver et al., 1986) were explained as consequences of the effects of temperature on oleic acid and linoleic acid desaturases (Burton, 1991). These effects include a decrease in oleic- and linoleic-desaturase activities at $35^{\circ} \mathrm{C}$ (Cheesbrough, 1989), a decrease in $\omega-6$ desaturase enzyme (encoded by the FAD2-1A gene), and the degradation of desaturases at high growth temperatures of $30^{\circ} \mathrm{C}$ (Tang et al., 2005). Another possible explanation for high linolenic and low oleic acids in late planting is that late planting coincides with a cooler temperature that favors linolenic acid accumulation and lowering of oleic acid. This explanation could be supported by our findings that linolenic acid concentration increased with increased SR for all PDs in sandy soil in 2009. This may be due to shade effects and cooler temperatures in the lower plant canopy which resulted from higher plant densities at higher SR (40 and 50 seed $\mathrm{m}^{-2}$ ). Previous research investigated the effect of upper and lower plant parts on seed nutrients, including seed oil and protein (Collins and Cartter, 1956), protein (Escalante and Wilcox, 1993), protein, oil, oleic, and linolenic acids (Bellaloui and Gillen, 2010; 
Bellaloui et al., 2012). They found that seed located at the top central portion had lower seed oil and higher protein contents (Collins and Cartter, 1956), while Kochegura (1982) found that seeds from the higher plant canopy had higher seed protein than seeds at lower plant canopy. Other researchers found that there were no differences between the upper and lower canopy (Huskey et al., 1990). Bellaloui et al. (2012) found that the lower plant canopy had higher oil and linolenic acid, but lower protein and oleic acid. The differences in seed oil between the upper and lower plant canopy was explained to be due to environmental differences during seed oil synthesis and accumulation (Collins and Cartter, 1956). Others reported that the higher seed oil and linolenic acid and the lower protein and oleic acids in seeds in the upper plant canopy was due to cooler temperature and shade effects as cooler temperature enhances linolenic acid and oil (Bellaloui et al., 2012). Therefore, the higher linolenic acid concentration with increasing SR and late planting could be due to shade effects and cooler temperature. Since linolenic acid and oleic acid showed to have an inverse relationship (Bellaloui et al., 2009a,b), the lower oleic acid is a consequences of the higher linolenic acid.

Increasing protein and B with increasing SR in 2009 in sandy and clay soils, especially for May and June plantings, increasing linolenic acid in sandy soil in April planting, and increasing sucrose in 2009 in both clay and sandy soils indicated the positive response of these constituents to SR increases under these conditions. The higher concentrations of $\mathrm{B}$ and sucrose in twin-rows, compared to single-rows, for all PDs in 2009 can be explained in terms of light interception and row-spacing effects. Twin-rows resulted in narrow-plantings, while single-row plantings were wider. It was reported that narrow-row soybean had higher canopy radiation interception than wider rows (Shibles and Weber, 1966; Taylor et al., 1982), and differences in radiation interception was observed between narrow-row and wide-rows during the period from R6 (beginning seed-fill) to R7 (full seed-fill) stages (Fehr and Caviness, 1977). These differences were attributed to leaf area distribution and duration (Taylor et al., 1982). Other researchers reported that the reasons for higher yield in narrower rows (from 25 to $50 \mathrm{~cm}$ ) compared to wider rows (Bharati, 1977; Cooper, 1977) was usually attributed to the development of a full canopy (95\% light interception) before rapid seed development (Shibles and Weber, 1966), resulting in greater photosynthetic rate (Shibles and Weber, 1965), and nutrient uptake and translocation (Bellaloui et al., 2014). Therefore, the higher concentrations of sucrose and $\mathrm{B}$ in twin-rows could be due to the possible association between sucrose and B nutrition and light interception and photosynthesis. The higher concentrations of oleic acid in 2010, especially in clay soil, may be due to higher temperature and a drier year in 2010 (Figure 1). The higher concentrations of stachyose in 2010 may be due to a drier year and higher temperature in 2010 compared with 2009, suggesting a possible role of stachyose as an environmental stress compound under drought and high temperature. Although the biological functions of stachyose are still not clear (Ren et al., 2009), Obendorf (1997) reported that oligosaccharides, including stachyose, are required for the acquisition of desiccation tolerance during seed development and maturation, and could be involved in seed protection

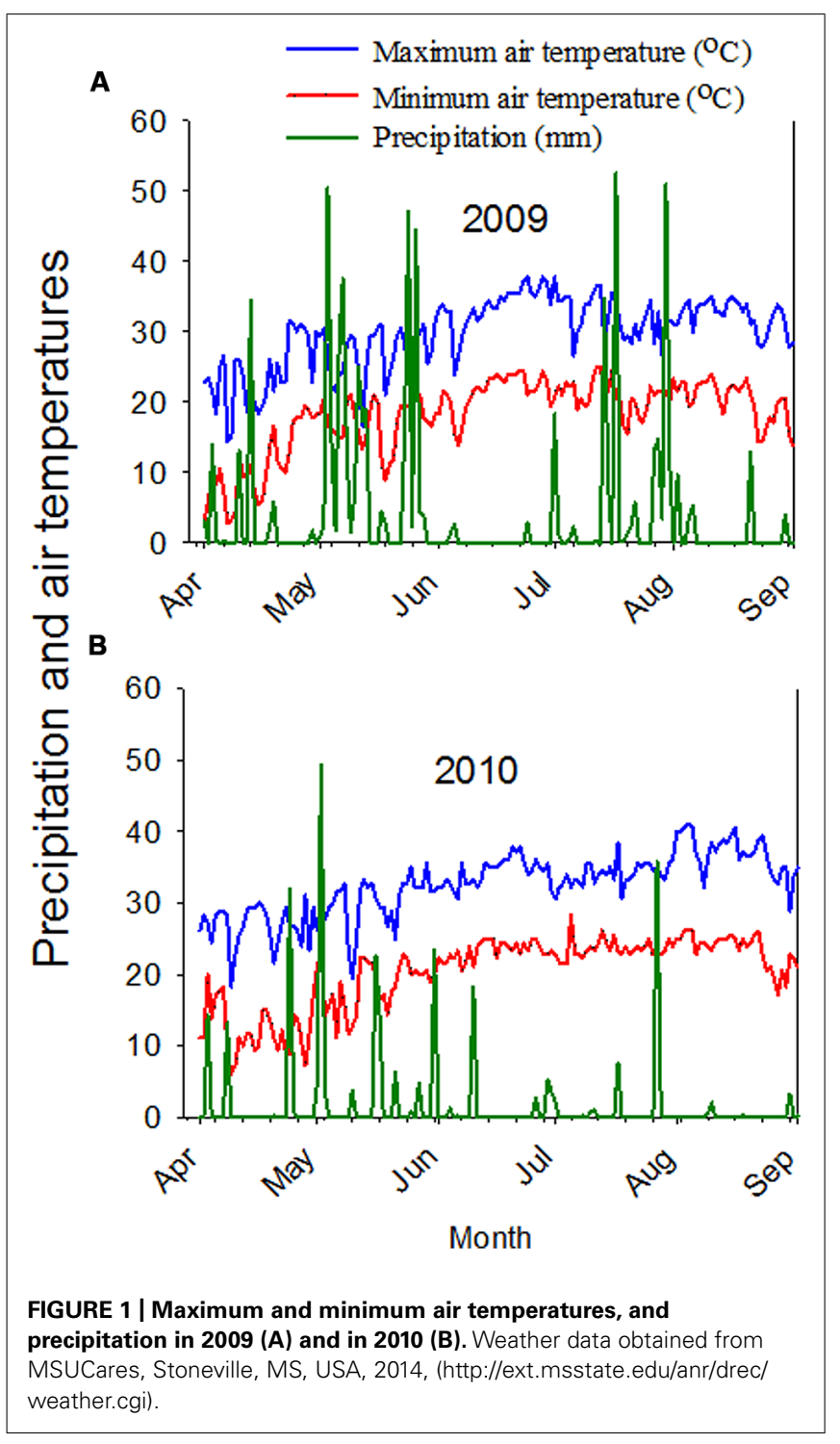

against damage during seed dehydration to ensure seed survival and storability.

Very limited information on the effects of SR and row-spacing on seed composition was reported, and what is available is on other species (Bellaloui et al., 2014). For example, effect of SR and row-spacing on seed protein and oil in rapeseed (Brassica napus L.) had no consistent effects (Kondra, 1975). Other researchers evaluated the effects of three row-spacing $(30,40$, and $50 \mathrm{~cm})$ on canola seed oil and found there was no relationship between rowspacing and oil, but the highest oil concentration was recorded at row-space of $30 \mathrm{~cm}$ (Mousavi et al., 2011). Studying the effects of SRs of $60,50,40$, and 30 plants $\mathrm{m}^{-2}$ on safflower (Carthamus tinctorius L.) oil under irrigated and rainfed conditions, Amoghein et al. (2012) found that the highest oil percentage was achieved by the lowest SR of 30 plants $\mathrm{m}^{-2}$, but no oil differences was observed between 40,50 , and 60 plant $\mathrm{m}^{-2}$. SR from 30,000 to 45,000 plants $\mathrm{ha}^{-1}$ resulted in higher oil in Sunflower (Helianthus annuus L.), while SR beyond 45,000 plants $\mathrm{ha}^{-1}$ resulted in a smaller increases 
(Gubbels and Dedio, 1986). Recently, Bellaloui et al. (2014) investigated the effects of SR and row-spacing on seed protein, oil, fatty acids, sugars, and minerals using four soybean cultivars (P 93M90, AG 3906, P 94B73, and V 52N3) in 2006 and 2007 in the Midsouth USA. They found that protein, oleic acid, sugars, $\mathrm{P}$, and $\mathrm{B}$ concentrations increased with the increase of SR in P 93M90 and AG 3906, but the concentrations of these constituents decreased after the maximum concentrations were reached, supporting our results. The pattern of increase was mainly observed in 2006 and depended on the row-spacing. In 2007, however, the opposite trend (protein and oleic decreased with SR) was noticed. In cultivars $\mathrm{P} 94 \mathrm{~B} 73$ and V 52N3 protein concentration increased with SR in 2006 and 2007 for both 38 and $76 \mathrm{~cm}$ row-spacing. An increase of oleic acid and a decrease of linolenic acid with row-spacing were observed in 2006. They concluded that SRs and row-spacing can alter some seed composition constituents, and the effect of SRs depended on the rate used, row-spacing, genotype, and the growing conditions of each year. They also reported that the different pattern (positive or negative) of seed constituents between years due to the environmental factors such as temperature and drought.

The response of some seed constituents to $\mathrm{PD}, \mathrm{SR}$, or RT was different between 2009 and 2010, and this may be due to high heat and drier year in 2010 . Weather data showed that the average maximum temperature reached $34^{\circ} \mathrm{C}$ in July and $37^{\circ} \mathrm{C}$ in August in 2010 compared with 32.2 and $34.4^{\circ} \mathrm{C}$ in July and August, respectively in 2009 (Figure 1; MSUCares, 2014). The precipitation in July was 46.0 and $6.1 \mathrm{~mm}$ in August in 2010, but was $203.7 \mathrm{~mm}$ in July and $36.1 \mathrm{~mm}$ in August in 2009 (Figure 1; MSUCares, 2014). Previous research showed that relationships between seed composition constituents differ between years due to heat and drought (Bellaloui et al., 2009b, 2014). Our soil analysis showed that both clay and sandy soils had adequate nutrient levels; however, leaf samples collected in 2009 and 2010 showed that leaf nutrient levels in 2010 were lower than in 2009, and this may be due to high heat and drier year in 2010, affecting the concentrations of seed composition and minerals.

We did not observe clear patterns for protein, oil, or fatty acids between single- and twin-rows, although other researchers found that row-spacing and irrigation significantly affected protein and oil contents, and that row-spacing (RS) of $70 \mathrm{~cm}$ had the highest protein content, followed by $\mathrm{RS}$ of 60,40 , and $50 \mathrm{~cm}$, respectively (Boydak et al., 2002). They also found that RS had a significant $(P<0.01)$ influence on oleic and linoleic acid content, and a rowspacing of $50 \mathrm{~cm}$ produced maximum oil value, but a row-spacing of $70 \mathrm{~cm}$ produced the highest protein value $(39.05 \%)$, and $50 \mathrm{~cm}$ produced the lowest value $(37.65 \%)$.

\section{CONCLUSION}

The current research showed that early planting resulted in higher soybean seed oil and oleic acid, but lower protein and linolenic acid concentrations. The late planting resulted in higher protein and linolenic acid. These changes in seed constituents were attributed mainly to temperature changes and drought, indicating that shifts in PDs create a new environment. Concentrations of protein, linolenic acid, sucrose and B increased with SR increases, possibly due to higher light interception and early canopy closure. The SRs that resulted in highest levels of seed constituents (for example, for protein, oil, oleic and linolenic acids, sucrose, and B) appear to be between 30 and 40 seed $\mathrm{m}^{-2}$. Rates beyond 40 seed $\mathrm{m}^{-2}$ may result in a negative effect on some seed constituents, possibly due to interplant competition for available nutrients and shade effects. The constituents most affected by management practices, and in our case PD, SR, and RT, appear to be protein, oleic and linolenic acids, sucrose, and B. Since the physiological and biochemical mechanisms of how management practices affect seed constituents are scarce, further research is needed to understand the mechanisms controlling these responses. The increase of stachyose in 2010 may be due to a drier year and high temperature in 2010 compared with 2009, suggesting a possible role of stachyose as an environmental stress compound, and further research is needed to confirm this observation. The current information benefits growers and breeders for considering environmental factors such as heat, drought, and agronomic practices in producing seed with higher quality, especially under double-cropping production systems of soybean and wheat in the Midsouth USA.

\section{ACKNOWLEDGMENTS}

Authors are thankful to Debbie Boykin for statistics assistance, Sandra Mosley for lab assistance, and Joseph Baugh for field management. This work was partially supported by the U.S. Department of Agriculture, Agricultural Research Service Project 6402-21220-012-00D. Mention of trade names or commercial products in this publication is solely for the purpose of providing specific information and does not imply recommendation or endorsement by the U.S. Department of Agriculture.

\section{REFERENCES}

Amoghein, R. S., Tobeh, A., and Jamaati-e-Somarin, S. (2012). Effect of plant density on phenology and oil yield of safflower herb under irrigated and rainfed planting systems. J. Med. Plant. Res. 6, 2493-2503.

AOAC. (1990a). “Method 988.05," in Official Methods of Analysis, 15th Edn, ed. K. Helrich (Arlington, VA: Elsevier Science Publishing).

AOAC. (1990b). “Method 920.39," in Official Methods of Analysis, 15th Edn, ed. K. Helrich (Arlington, VA: Elsevier Science Publishing).

Bachlava, E., and Cardinal, A. J. (2009). Correlation between temperature and oleic acid seed content in three segregating soybean populations. Crop Sci. 49, 1328-1335. doi: 10.2135/cropsci2008.11.0660

Bandemer, S. L., and Schaible, P. J. (1944). Determination of iron. A study of the o-phenanthroline method. Ind. Eng. Chem. Anal. Ed. 16, 317-319. doi: 10.1021/i560129a013

Bellaloui, N., Abbas, H. K., Gillen, A. M., and Abel, C. A. (2009a). Effect of glyphosate-boron application on seed composition and nitrogen metabolism in glyphosate-resistant soybean. J. Agric. Food Chem. 57, 9050-9056. doi: 10.1021/jf901801z

Bellaloui, N., Smith, J. R., Ray, J. D., and Gillen, A. M. (2009b). Effect of maturity on seed composition in the early soybean production system as measured on near-isogenic soybean lines. Crop Sci. 49, 608-620. doi: 10.2135/cropsci2008.0 4.0192

Bellaloui, N., and Gillen, A. M. (2010). Soybean seed protein, oil, fatty acids, N, and S partitioning as affected by node position and cultivar differences. Agric. Sci. 1, $110-118$.

Bellaloui, N., Mengistu, A., and Paris, D. R. (2008). Soybean seed composition in cultivars differing in resistance to charcoal rot (Macrophomina phaseolina). J. Agric. Sci. 146, 667-675. doi: 10.1017/S0021859608007971

Bellaloui, N., Mengistu, A., Walker, E. R., and Young, L. D. (2014). Soybean seed composition as affected by seeding rates and row spacing. Crop Sci. 54, 1782-1795. doi: 10.2135/cropsci2013.07.0463

Bellaloui, N., Smith, J. R., Gillen, A. M., Fisher, D. K., and Mengistu, A. (2012). Effect of shade on seed protein, oil, fatty acids, and minerals in soybean lines varying 
in seed germinability in the early soybean production system. Am. J. Plant Sci. 3, 84-95. doi: 10.4236/ajps.2012.31008

Bellaloui, N., Smith, J. R., Gillen, A. M., and Ray, J. D. (2010). Effect of maturity on seed sugars as measured on near-isogenic soybean (Glycine max) lines. Crop Sci. 50, 1978-1987. doi: 10.2135/cropsci2009.10.0596

Bellaloui, N., Smith, J. R., Gillen, A. M., and Ray, J. D. (2011). Effects of maturity, genotypic background, and temperature on seed mineral composition in nearisogenic soybean lines in the early soybean production system. Crop Sci. 51, 1161-1171. doi: 10.2135/cropsci2010.04.0187

Bharati, M. P. (1977). Density and environment interaction in soybeans: a review. Nepalese. J. Agric. 12, 239-247.

Bouis, H. E. (2003). Micronutrient fortification of plants through plant breeding: can it improve nutrition in man at low cost? Proc. Nutr. Soc. 62, 403-411. doi: 10.1079/PNS2003262

Boydak, E., Alpaslan, M., Hayta, M., Gerçek, S., and Simsek, M. (2002). Seed composition of soybeans grown in the Harran region of Turkey as affected by row spacing and irrigation. J. Agric. Food Chem. 50, 4718-4720. doi: 10.1021/jf02 55331

Bruns, H. A. (2011). Planting date, rate, and twin-row vs. single-row soybean in the Mid-South. Agron. J. 103, 1308-1313. doi: 10.2134/agronj2011.0076

Burton, J. W. (1991). Recent developments in breeding soy-beans for improved oil quality. Fat Sci. Tech. 93, 121-128.

Carver, B. F., Burton, J. W., Carter, T. E., and Wilson, R. F. (1986). Response to environmental variation of soybean lines selected for altered unsaturated fatty acid composition. Crop Sci. 26, 1176-1180. doi: 10.2135/cropsci1986.0011183X002600060021x

Cavell, A. J. (1955). The colorimetric determination of phosphorus in plant materials. J. Sci. Food Agric. 6, 479-480. doi: 10.1002/jsfa.2740060814

Chapman, G. W., Robertson, J. A., and Budrick, D. (1976). Chemical composition and lipoxygenase activity in soybean affected by genotype and environment. J. Am. Oil Chem. Soc. 53, 54-56. doi: 10.1007/BF02637391

Cheesbrough, T. M. (1989). Changes in the enzymes for fatty acid synthesis and desaturation during acclimation of developing soybean seeds to altered growth temperature. Plant Physiol. 90, 760-764. doi: 10.1104/pp.90 2.760

Chy, W. S., and Sheldon, V. L. (1979). Soybean oil quality as influenced by planting site and variety. J. Am. Oil Chem. Soc. 56, 71-75. doi: 10.1007/BF02914271

Collins, F. I., and Cartter, J. L. (1956). Variability in chemical composition of seed from different portions of the soybean plant. Agron. J. 48, 216-219. doi: 10.2134/agronj1956.00021962004800050006x

Cooper, R. L. (1977). Response of soybean cultivars to narrow rows and planting rates under weed free conditions. Agron. J. 69, 89-92. doi: 10.2134/agronj1977.00021962006900010023x

Dardanelli, J. L., Balzarini, M., Martinez, M. J., Cuniberti, M., Resnik, S., Ramunda, S. F., et al. (2006). Soybean maturity groups, environments, and their interaction define mega-environments for seed composition in Argentina. Crop Sci. 46, 1939 1947. doi: 10.2135/cropsci2005.12-0480

Devirian, T. A., and Volpe, S. L. (2003). The physiological effects of dietary boron. Crit. Rev. Food Sci. Nutr. 43, 219-231. doi: 10.1080/10408690390826491

Dordas, C., Apostolides, G., and Goundra, O. (2007). Boron application affects seed yield and seed quality of sugarbeets. J. Agric. Sci. 145, 377-384. doi: $10.1017 /$ S0021859607006879

Dornbos, D. L., and Mullen, R. E. (1992). Soybean seed protein and oil contents and fatty-acid composition adjustments by drought and temperature. J. Am. Oi Chem. Soc. 69, 228-231. doi: 10.1007/BF02635891

Ebelhar, M. W. (2010). Twin-row corn boosts yields. Corn \& Soybean Digest. Available at: http://cornandsoybeandigest.com/corn/twin-row-cornboosts-yields [accessed June 21, 2011].

Escalante, E. E., and Wilcox, J. R. (1993). Variation in seed protein among nodes of normal- and high-protein soybean genotypes. Crop Sci. 33, 1164-1166. doi: 10.2135/cropsci1993.0011183X003300060011x

Fehr, W. R., and Caviness, C. E. (1977). Stages of soybean development. Iowa Coop. Ext. Serv. Iowa Agric. Home Econ. Exp. Stn. Spec. Rep. 80:11.

Gubbels, G. H., and Dedio, W. (1986). Effect of plant density and soil fertility on oilseed sunflower genotypes. Can. J. Plant Sci. 66, 521-527. doi: 10.4141/cjps 86-071

Harue, T., and Hirokadzu, T. (1971). Influence of location on the chemical composition of soybean seeds. Proc. Crop Sci. Soc. Jpn. 40, 530-534. doi: $10.1626 /$ jcs. 40.530
Heatherly, L. (2014). Doublecropping in the Midsouth. Mississippi Soybean Promotion Board (MSPB). Available at: http://mssoy.org/blog/doublecropping-in-themidsouth/ [accessed July 10, 2014].

Heatherly, L. G. (1999). "Early soybean production system (ESPS)," in Soybean Production in the Midsouth, eds L. G. Heatherly, and H. F. Hodges (Boca Raton, FL: CRC Press), 103-118.

Heatherly, L. G., Blaine, A., Hodges, H. F., Wesley, R. A., and Buehring, N. (1999). "Variety selection, planting dates, row spacing, and seeding rate," in Soybean Production in the Midsouth, eds L. G. Heatherly and H. F. Hodges (New York: CRC Press), 41-47.

Helms, T. C., Hurburgh, C. R. Jr., Lussenden, R. L., and Whited, D. A. (1990). Economic analysis of increased protein and decreased yield due to delayed planting of soybean. J. Prod. Agric. 3, 367-371. doi: 10.2134/jpa1990.0367

Howell, R. W., and Collins, F. I. (1957). Factors affecting linolenic and linoleic acid content of soybean oil. Agron. J. 49, 593-597. doi: 10.2134/agronj1957.00021962004900110007x

Huskey, L. L., Snyder, H. E., and Gbur, E. E. (1990). Analysis of single soybean seeds for oil and protein. J. Am. Oil Chem. Soc. 67, 686-688. doi: 10.1007/BF02540423

Jaureguy, L. M., Rodriguez, F. L., Zhang, L., Chen, P., Brye, K., Oosterhuis, D., et al. (2013). Planting date and delayed harvest effects on soybean seed composition. Crop Sci. 53, 2162-2175. doi: 10.2135/cropsci2012.12.0683

John, M. K., Chuah, H. H., and Neufeld, J. H. (1975). Application of improved azomethine-H method to the determination of boron in soils and plants. Anal. Lett. 8, 559-568. doi: 10.1080/00032717508058240

Kane, M. V., Steele, C. C., Grabau, L. J., MacKown, C. T., and Hildebrand, D. F. (1997). Early- maturing soybean cropping system: III. Protein and oil contents and oil composition. Agron. J. 89, 464-469. doi: 10.2134/agronj1997.00021962008900030016x

Kochegura, A. V. (1982). Differences in seed quality within the plant. Selektsiya I Semenovodstovo USSR 9, 24-25.

Kondra, Z. P. (1975). Effects of row spacing and seeding rate on rapeseed. Can. J. Plant Sci. 55, 339-341. doi: 10.4141/cjps75-052

Lehrsch, G. A., Whislerb, F. D., and Buehringc, N. W. (1994). Cropping system influences on extractable water for mono- and double-cropped soybean. Agric. Water Manage. 26, 13-25. doi: 10.1016/0378-3774(94)9 0021-3

Liu, K. (1997). Soybeans Chemistry, Technology, and Utilization. New York: Chapman \& Hall.

Loeppert, R. L., and Inskeep, W. P. (1996). "Colorimetric determination of ferrous iron and ferric iron by the 1,10-phenanthroline method," in Methods of soil analysis: Part 3, Chemical methods, ed. J. M. Bigham (Madison, WI: SSSA), 659-661.

Lohse, G. (1982). Microanalytical azomethine-H method for boron determination in plant tissue. Commun. Soil Sci. Plant Anal. 13, 127-134. doi: $10.1080 / 00103628209367251$

Lu, K., Li, L., Zheng, X., Zhang, Z., Mou, T., and Hu, Z. (2008). Quantitative trait loci controlling $\mathrm{Cu}, \mathrm{Ca}, \mathrm{Zn}, \mathrm{Mn}$, and Fe content in rice grains. J. Genet. 87, 305-310. doi: 10.1007/s12041-008-0049-8

Mascagni, H. J. R., Clawson, E., Lanclos, D., Boquet, D., and Ferguson, R. (2008). Comparing Single-Row, Twin-Row Configurations for Louisiana crop Production. LSU, Ag Center, Research \& Extension. Available at:http://text.lsuagcenter.com/en/communications/publications/agmag/Archive/ 2008/Summer/Comparing+SingleRow+TwinRow+Configurations+for+Louis iana+Crop+Production.htm [accessed July 13, 2014].

Mengistu, A., Castlebury, L. A., Smith, J. R., Rossman, A. Y., and Reddy, K. N. (2007). Identification and pathogenicity of Phomopsis isolates from weed hosts and their effect on soybean. Can. J. Plant Pathol. 29, 283-289. doi: 10.1080/07060660709507471

Mengistu, A., and Heatherly, L. G. (2006). Planting date, irrigation, maturity group, year, and environment effects on Phomopsis longicolla, seed germination, and seed health rating of soybean in the early soybean production system of the mid-southern USA. Crop Prot. 25, 310-317. doi: 10.1016/j.cropro.2005. 05.011

Minor, H. C., and Wiebold, W. J. (1998). Soybean-wheat double crop management in Missouri. MU Extension, University of Missouri-Columbia. Available at: http://extension.missouri.edu/p/G4953 [accessed July 10, 2014].

Mousavi, S. J., Sam-Daliri, M., and Bagheri, H. (2011). Study of planting density on some agronomic traits of rapeseed three cultivar (Brassica napus L.). Aust. J. Basic Appl. Sci. 5, 2625-2627. 
MSUCares. (2014). Mississippi State University, Extension service. Available at: http://ext.msstate.edu/anr/drec/weather.cgi [accessed August 20, 2014].

Obendorf, R. L. (1997). Oligosaccharides and galactosyl cyclitols in seed desiccation tolerance. Seed Sci. Res. 7, 63-74. doi: 10.1017/S09602585000 $0341 \mathrm{X}$

Pedersen, P., and Lauer, J. G. (2004). Response of soybean yield components to management system and planting date. Agron. J. 96, 1372-1381. doi: 10.2134/agronj2004.1372

Piper, E. L., and Boote, K. J. (1999). Temperature and cultivar effects on soybean seed oil and protein concentrations. J. Am. Oil Chem. Soc. 76, 1233-1242. doi: 10.1007/s11746-999-0099-y

Ray, J. D., Heatherly, L. G., and Fritschi, F. B. (2006). Influence of large amounts of nitrogen on non-irrigated and irrigated soybean. Crop Sci. 46, 52-60. doi: $10.2135 /$ cropsci2005.0043

Ren, C., Bilyeu, K. D., and Beuselinck, P. R. (2009). Composition, vigor, and proteome of mature soybean seeds developed under high temperature. Crop Sci. 49, 1010-1022. doi: 10.2135/cropsci2008.05.0247

Samman, S., Naghii, M. R., Lyons Wall, P. M., and Verus, A. P. (1998). The nutritional and metabolic effects of boron in humans and animals. Biol. Trace Elem. Res. 66, 227-235. doi: 10.1007/BF02783140

Schnebly, S. R., and Fehr, W. R. (1993). Effect of years and planting dates on fatty acid composition of soybean genotypes. Crop Sci. 33, 716-719. doi 10.2135/cropsci1993.0011183X003300040016x

Shibles, R. M., and Weber, C. R. (1965). Leaf area, solar radiation interception and dry matter production by soybeans. Crop Sci. 5, 575-577. doi: 10.2135/cropsci1965.0011183X000500060027x

Shibles, R. M., and Weber, C. R. (1966). Interception of solar radiation and dry matter production by various soybean planting patterns. Crop Sci. 6, 55-59. doi: 10.2135/cropsci1966.0011183X000600010017x

Smith, J. R., Mengistu, A., Nelson, R. L., and Paris, R. L. (2008). Identification of soybean accessions with high germinability in high-temperature environments. Crop Sci. 48, 2279-2288. doi: 10.2135/cropsci2008.01.0026

Tang, G. O., Novitzky, W. P., Griffin, H. C., Huber, S. C., and Dewey, R. E. (2005). Oleate desaturase enzymes of soybean: evidence of regulation through differential stability and phosphorylation. Plant J. 44, 433-446. doi: 10.1111/j.1365-313X.2005.02535.x
Taylor, H. M., Mason, W. K., Bennie, A. T. P., and Rowse, H. R. (1982). Responses of soybeans to two row spacings and two soil water levels. I. An analysis of biomass accumulation, canopy development, solar radiation interception and components of seed yield. Field Crop Res. 5, 1-14. doi: 10.1016/0378-4290(82)90002-8

Welch, R. M., and Graham, R. D. (2004). Breeding for micronutrients in staple food crops from a human nutrition perspective. J. Exp. Bot. 55, 353-364. doi: 10.1093/jxb/erh064

White, P. J., and Broadley, M. R. (2009). Biofortification of crops with seven mineral elements often lacking in human diets - iron, zinc, copper, calcium, magnesium, selenium, and iodine. New Phytol. 182, 49-84. doi: 10.1111/j.1469-8137.2008.02738.x

Wilcox, J. R., and Cavins, J. F. (1992). Normal and low linolenic acid soybean strains: response to planting date. Crop Sci. 32, 1248-1251. doi: 10.2135/cropsci1992.0011183X003200050037x

Wilcox, J. R., and Cavins, J. F. (1995). Backcrossing high seed protein to a soybean cultivar. Crop Sci. 35, 1036-1041. doi: 10.2135/cropsci1995.0011183X003500040019x

Wilcox, J. R., and Shibles, R. M. (2001). Interrelationships among seed quality attributes in soybean. Crop Sci. 41, 11-14. doi: 10.2135/cropsci2001.41111x

Conflict of Interest Statement: The authors declare that the research was conducted in the absence of any commercial or financial relationships that could be construed as a potential conflict of interest.

Received: 21 November 2014; accepted: 13 January 2015; published online: 18 February 2015.

Citation: Bellaloui N, Bruns HA, Abbas HK, Mengistu A, Fisher DK and Reddy KN (2015) Agricultural practices altered soybean seed protein, oil, fatty acids, sugars, and minerals in the Midsouth USA. Front. Plant Sci. 6:31. doi: 10.3389/fpls.2015.00031 This article was submitted to Crop Science and Horticulture, a section of the journal Frontiers in Plant Science.

Copyright (C) 2015 Bellaloui, Bruns, Abbas, Mengistu, Fisher and Reddy. This is an open-access article distributed under the terms of the Creative Commons Attribution License (CC BY). The use, distribution or reproduction in other forums is permitted, provided the original author(s) or licensor are credited and that the original publication in this journal is cited, in accordance with accepted academic practice. No use, distribution or reproduction is permitted which does not comply with these terms. 